Life Sciences Contribution Royal Ontario Museum

94

Contributions to the Systematics of the Caddisfly Family Limnephilidae (Trichoptera). I

Glenn B. Wiggins

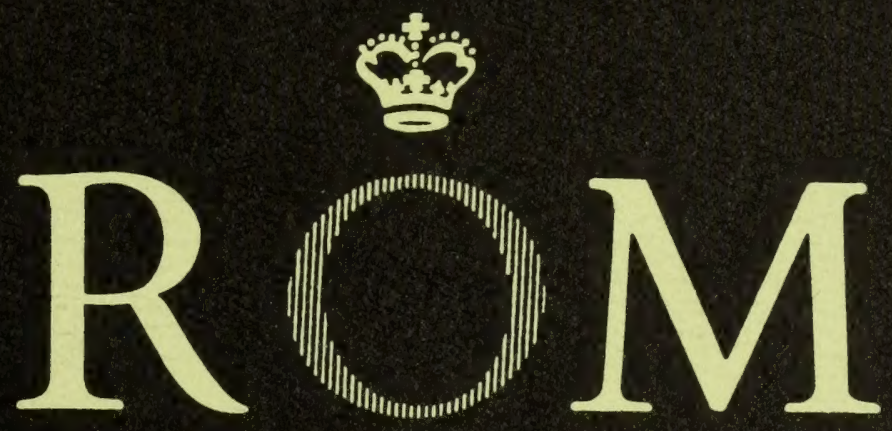


Digitized by the Internet Archive in 2011 with funding from University of Toronto 
LIFE SCIENCES CONTRIBUTIONS

ROYAL ONTARIO MUSEUM

NUMBER 94

GLenN B. wiggins Contributions to the Systematics of the Caddisfly Family

Limnephilidae (Trichoptera). I 


\section{ROYAL ONTARIO MUSEUM \\ PUBLICATIONS IN LIFE SCIENCES}

The Royal Ontario Museum publishes three series in the Life Sciences:

LIFE SCIENCES CONTRIBUTIONS, a numbered series of original scientific publications, including monographic works.

LIFE SCIENCES OCCASIONAL PAPERS, a numbered series of original scientific publications, primarily short and usually of taxonomic significance.

LIFE SCIENCES MISCELLANEOUS PUBLICATIONS, an unnumbered series of publications of varied subject matter and format.

All manuscripts considered for publication are subject to the scrutiny and editorial policies of the Life Sciences Editorial Board, and to review by persons outside the Museum staff who are authorities in the particular field involved.

\section{LIFE SCIENCES EDITORIAL BOARD}

Chairman: R. L. PETERSON

Editor: D. BARR

Associate Editor: J. C. BARLOW

Associate Editor: J. R. TAMSITT

GLENN B. WIGGINS is Curator of the Department of Entomology and Invertebrate Zoology, Royal Ontario Museum, and Professor in the Department of Zoology, University of Toronto.

PRICE： $\$ 2.00$

(C) The Royal Ontario Museum, 1973

100 Queen's Park, Toronto, Canada

PRINTED AT THE BRYANT PRESS LIMITED 


\title{
Contributions to the Systematics of the Caddisfly Family Limnephilidae (Trichoptera). I
}

\begin{abstract}
Several genera of limnephilid Trichoptera occurring in western North America are particularly significant in the phylogeny and classification of the family because of their ambiguous relationships with other taxa. This paper provides new data from larval and pupal morphology for certain of these critical genera: Imania (scotti sp. nov.), Manophylax gen. nov. (annulatus sp. nov.) and Moselyana (comosa Denning). Adults of these species are also described, along with all stages of a species of Apatania (arizona sp. nov.).

Preliminary assessment of ancestral and derived characters is made for larvae of the Limnephilidae. Using these criteria, analysis of larval characters is made for the limnephilid subfamilies and for the genera Moselyana, Imania, and Manophylax. The analysis indicates that these three genera are not congruent with any of the subfamilies as now constituted, including the Apataniinae with which the two former genera have been classified. The analysis further indicates that larvae of Imania and Moselyana have few derivative characters in common, suggesting that these two genera are not as closely related as has been interpreted from the adults.
\end{abstract}

\section{Introduction}

Caddisflies of the family Limnephilidae occur in temperate areas in most parts of the world, but have been especially successful in the northern hemisphere where they are the dominant group. An important synopsis of the relationships and classification of the world fauna was made by Schmid (1955), and a considerable literature on the family has accumulated since that time. As relationships of the world fauna of the family become clearer, it appears that several genera in the fauna of western North America do not fit readily into interpretations of broad relationships and classification that seem to accommodate most taxa of the family. These genera include Imania, Moselyana, Neothremma, Farula, Homophylax and Lepania. Thus, additional evidence concerning relationships of these taxa has some general bearing on the systematics of the entire family.

Field work carried out by staff of the Department of Entomology and Invertebrate Zoology of the Rом in western North America during the past few years has, among other things, resulted in establishment of the first 
larval-pupal-adult associations for most of these anomalous genera and also in the discovery of several new species. New data for the genus Lepania are being published separately (Wiggins, 1973).

In the present paper, new data on larval and pupal morphology are provided for Moselyana, Imania and a new genus Manophylax. New species in Imania, Manophylax and Apatania are described. Interpretation of relationships for Moselyana, Imania and Manophylax, based on the data from larvae, lead to different conclusions from those based previously on adults.

\section{Materials and methods}

Associations among larval, pupal, and adult stages were established by rearing or by collection of larvae and mature pupae with cast larval sclerites. Unless otherwise indicated, all specimens are deposited in the Royal Ontario Museum. Quantitative data expressed as a range from minimum to maximum are followed, in parentheses, by the number of specimens on which the data are based. Length of larva expresses length of final instar on the linear axis between anterior and posterior limits of specimens in the position shown in the habit illustrations (Figs. 4a, 16a, 28a, 39a). Measurements were made with a Zeiss eyepiece micrometer at $10 \mathrm{X}$ magnification, and converted to millimetres by a Leitz calibration scale.

\section{Systematic Data}

\section{A patania arizona sp. nov.}

This species belongs to the fimbriata group, malaisei subgroup (sensu Schmid, 1953, 1954). It is the first North American species to be discovered in this otherwise Asiatic subgroup, thus representing another evolutionary line of apataniine Trichoptera which has undergone Holarctic dispersal.

ADUlT. Among species now known, A. arizona bears closest general similarity to A. brevis Mosely from Kashmir (Schmid, 1954, figs. 77, 78) but can be readily distinguished by characters of the male and female genitalia.

Length of forewing: male 7.9-8.7 mm (10); female 8.6-9.1 $\mathrm{mm}$ (6). Body medium brown, major setae of head and thorax brownish-yellow; antennae medium brown; palpi, femora, tibiae and tarsi light brown. Forewings with dense covering of brown hairs, no markings; venation (Fig. 3 ) similar in both sexes.

Male Genitalia (Fig. 1). Distinguished most readily from $A$. brevis by the terminal segment of the clasper which is acutely pointed in lateral view rather

Figs. 1-3 Apatania arizona sp. nov. adults. 1. Male genitalia: a, lateral view, X50; b, dorsal view, X50; c, ventral view, X50; d, phallus, ventral view, X53; e, phallus, lateral view, X53; ext. br., seg. X-external branch, segment X; int. br., seg. $\mathrm{x}$-internal branch, segment $\mathrm{x}$; pr. app., seg. $\mathrm{x}$-praeanal appendage, segment x. 2. Female genitalia: a, lateral view, X40; b, ventral view, X40; sg. plate-supragenital plate; VIII, IX, X-abdominal segment vIII, etc. 3. Wings, $X 9$. 

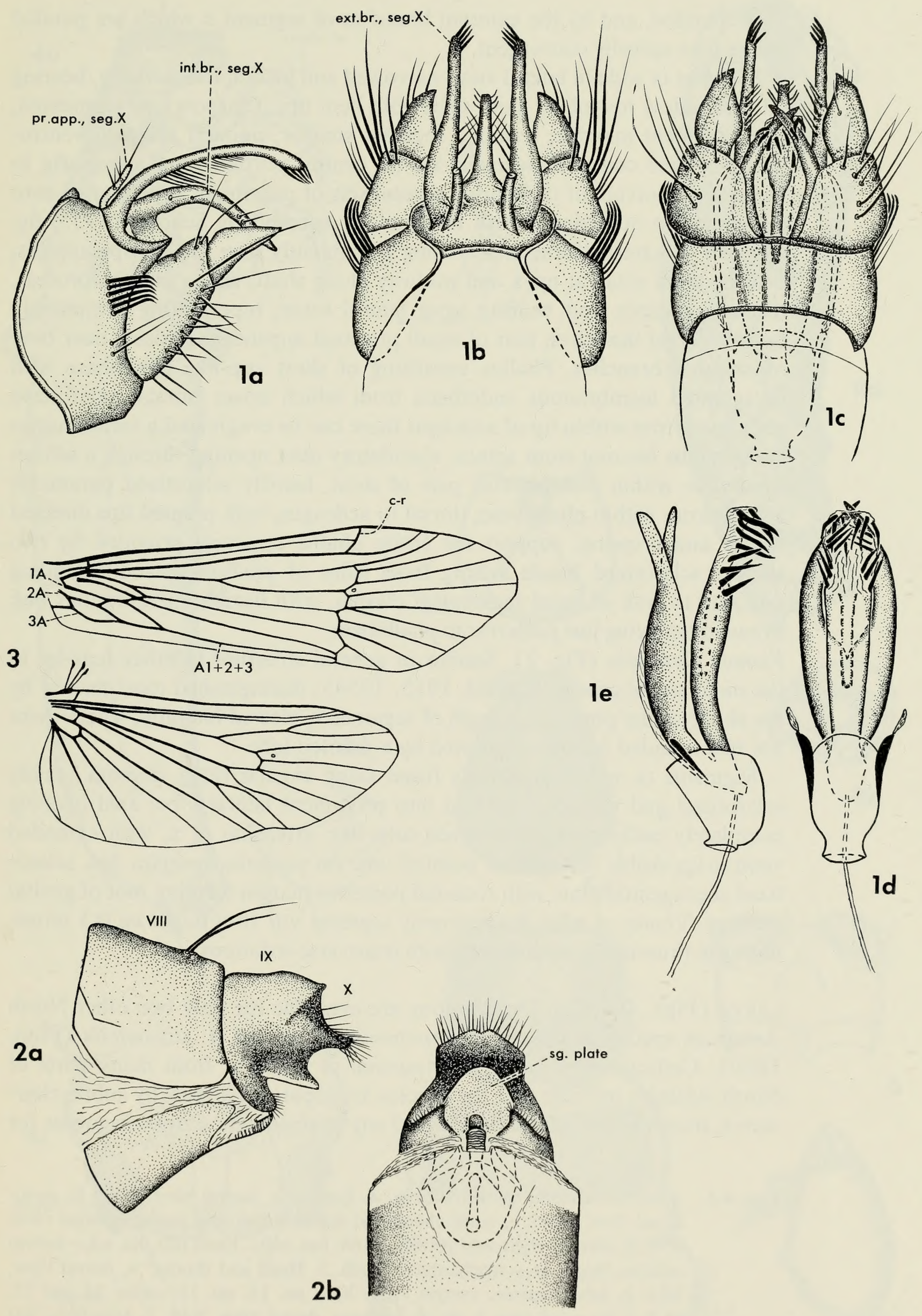
than rounded, and by the external branches of segment $\mathrm{x}$ which are parallel rather than apically convergent.

Segment IX wide in lateral view, narrowed and incomplete dorsally, bearing on each side a row of six stout setae with bent tips. Claspers two-segmented, basal segment massive; terminal segment smaller, pointed apically, ventromesal surface concave. Segment $\mathrm{x}$ with central portion fused anteriorly to incomplete dorsum of IX, bearing several sets of prominent appendages, here designated in accordance with terminology adopted by Schmid (1955, fig. 3 ) : pair of external branches arching prominently over genital appendages, bearing stout setae at apex and midway along shaft; single median process, truncate at apex and bearing stout lateral setae, representing presumably fused internal branches; pair of small praeanal appendages arising near base of external branches. Phallus consisting of short cup-like phallobase with invaginated membranous endotheca from which arises tubular sclerotized aedeagus; from within tip of aedeagus there can be evaginated a membranous endophallus bearing stout spines; ejaculatory duct opening through a sclerotized tube within endophallus; pair of stout, heavily sclerotized parameres arising from within phallobase, dorsal to aedeagus, with pointed tips directed mesad and crossing; support for entire phallic structure provided by two slender sclerotized bands arising from sides of phallobase and extending posterad to wall of basal segment of clasper, with flexible membranous link in each band lying just posterior to phallobase.

Female Genitalia (Fig. 2). Similar in general structure to other females in the malaisei subgroup (Schmid, 1953, 1954); distinguished most readily by the shape of the posterior margin of segment $\mathrm{x}$, viewed laterally, where there are two rounded notches separated by a pointed lobe.

Segments IX and $\mathrm{X}$ apparently fused along angular ridge, dorsum heavily sclerotized and extended ventrad into prominent lateral lobe; anal opening completely enclosed by sclerotized tube-like extension of $\mathrm{x}$, with extended ventral lip visible laterally as pointed lobe on posterior margin; flat, sclerotized supragenital plate with rounded posterior margin forming roof of genital passage. Venter of what is apparently segment VIII (but might be IX) terminating in thumb-like median lobe with transverse striations.

LARVA (Figs. 4-7, 12). Descriptions are available for only two other North American species of this genus, Apatania incerta and A. stigmatella (Flint, 1960). Collections of larvae of Apatania in the RoM from many parts of North America indicate that the species are separable largely by subtle characters; thus it seems advisable to avoid any misleadingly simple diagnoses for

Figs. 4-8 Apatania arizona sp. nov. larva. 4. Larva: a, lateral view, X17; b, mesotarsal claw, X145; c, ninth abdominal segment and anal prolegs, dorsal view, X52; d, claw of right anal proleg, X164; bas. tuft-basal tuft; lat. scl.-lateral sclerite; troch. br.-trochanteral brush. 5. Head and thorax: a, dorsal view, X24; b, head capsule, ventral view, X24; no. 14, no. 15-setae 14 and 15; sa 1, 2, 3-setal area 1, etc. 6. Labrum, dorsal view, X69. 7. Mandible, left side, ventral view, X118. 8. Larval case: a, ventrolateral view, X10; b, posterior end of case, facial view, X10. 


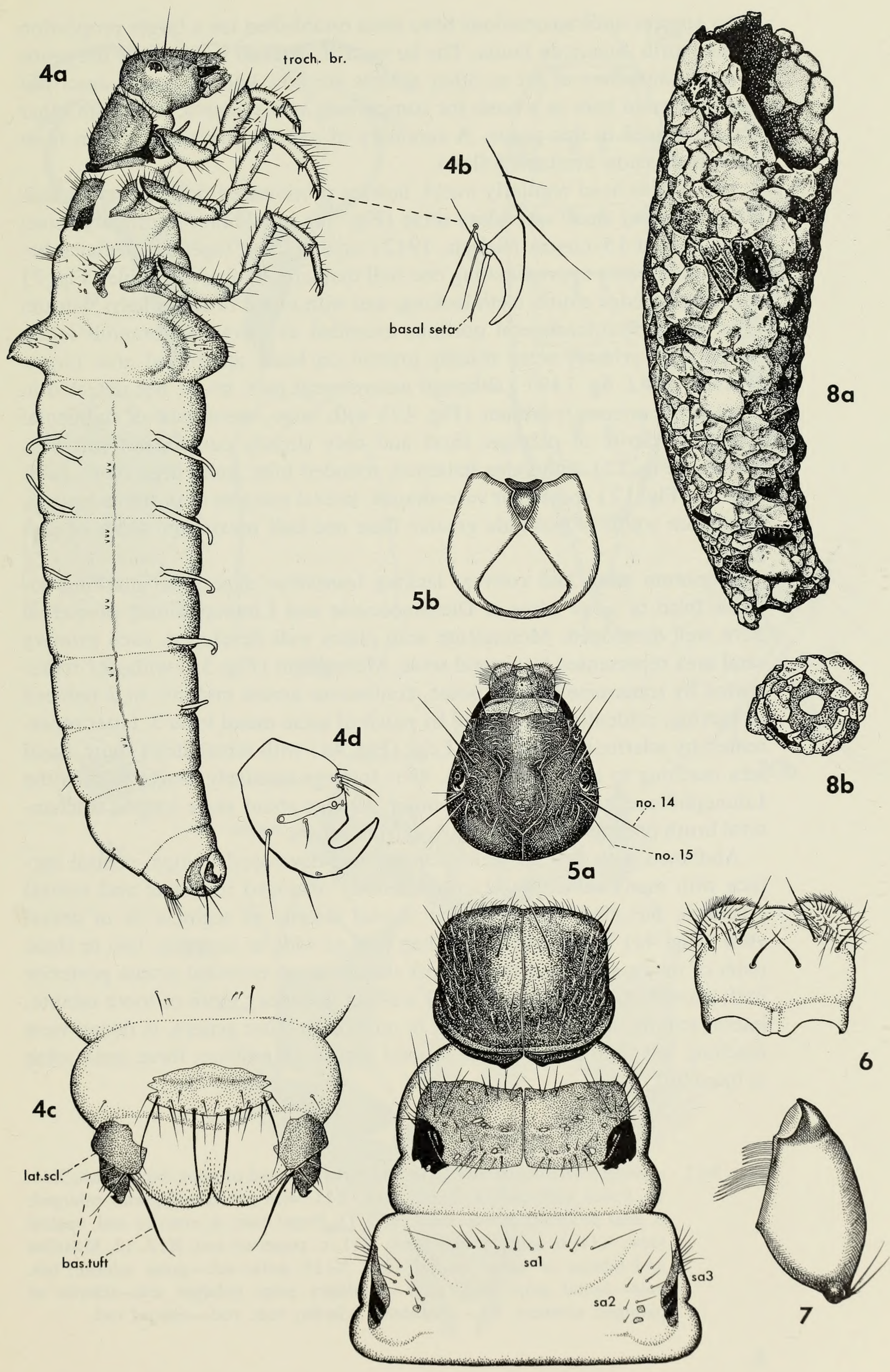


a few species until associations have been established for a larger proportion of the North American fauna. The larva of $A$. arizona is typical of the genus in most characters as far as other species are now known, and is described and illustrated here as a basis for comparison at the generic level with other taxa discussed in this paper. A summary of generic characters drawn from descriptions now available follows.

Larva with head regularly ovoid, lacking pronounced ridges, dorsum usually with many small secondary setae (Fig. 5a) in addition to primary setae; setae 14 and 15 (sensu Nielsen, 1942) arising close together, distance between their bases approximating one-half diameter of eye; mandible (Fig. 7) with cutting edge entire, teeth lacking, and with mesal brush of hairs; labrum (Fig. 6) with anterolateral portions extended as hairy membranous lobes, six pairs of primary setae usually present on basal sclerotized area (sensu Nielsen, 1942, fig. 149) (although anteromesal pair, no. 1, not detected in larva of $A$. arizona); labium (Fig. 12) with large, mesal pair of submental sclerites; sclerite of palpiger short and only slightly curved, not ring-like; maxilla (Fig. 12) with galea flattened, rounded lobe; gular area short, gular sclerite (Fig. 12) somewhat vase-shaped, lateral margins of postgula convex, maximum width of postgula greater than one-half maximum width of pregula.

Pronotum stout and convex, lacking transverse depression marking anterior third or so of plate in Dicosmoecinae and Limnephilinae; prosternal horn well developed. Mesonotum with plates well developed, each primary setal area represented by several setae. Metanotum (Fig. 5a) with sa 1 represented by transverse band of setae, continuous across midline; sa 2 reduced or lacking, evidently represented by patch of setae mesal to $s a 3$, latter represented by sclerite bearing setae. Legs (Fig. 4a) with tarsal claws short, basal seta reaching to tip of claw (Fig. 4b); forelegs relatively longer than in the Limnephilinae, segments more slender, all legs about same length; trochanteral brush present on forelegs, absent from others.

Abdomen with first segment bearing well-developed humps, ventral surface with many setae; single gills variously arranged in dorsal and ventral positions, but absent from lateral; dorsal sclerite of segment IX in dorsal view (Fig. 4c) considerably less than half as wide as segment, two or three pairs of major setae and many short slender setae crowded across posterior half; claw of anal prolegs (Fig. 4d) without accessory tooth or tooth minute; lateral sclerite of anal proleg small in relation to other genera, in dorsal view reaching less than half distance to anal fissure on midline; three stout setae in basal tuft.

Figs. 9-12 Apatania arizona sp. nov. pupa and larva. 9. Head of pupa, facial view, X41. 10. Pupal abdomen: a, dorsal view, X15, with sclerotized plates enlarged; $\mathrm{b}$, anal processes, dorsal view, X30. 11. Pupal case: a, anterior end, ventral view, X11; b, same, profile view, X11; c, posterior end, X11. 12. Maxillae and labium of larva, ventral view, X125; gular scl._-gular sclerite; lab. palp-labial palp; max. palp-maxillary palp; palpiger scl.-sclerite of palpiger; subment. scl.-submental sclerite; vent. rod-ventral rod. 

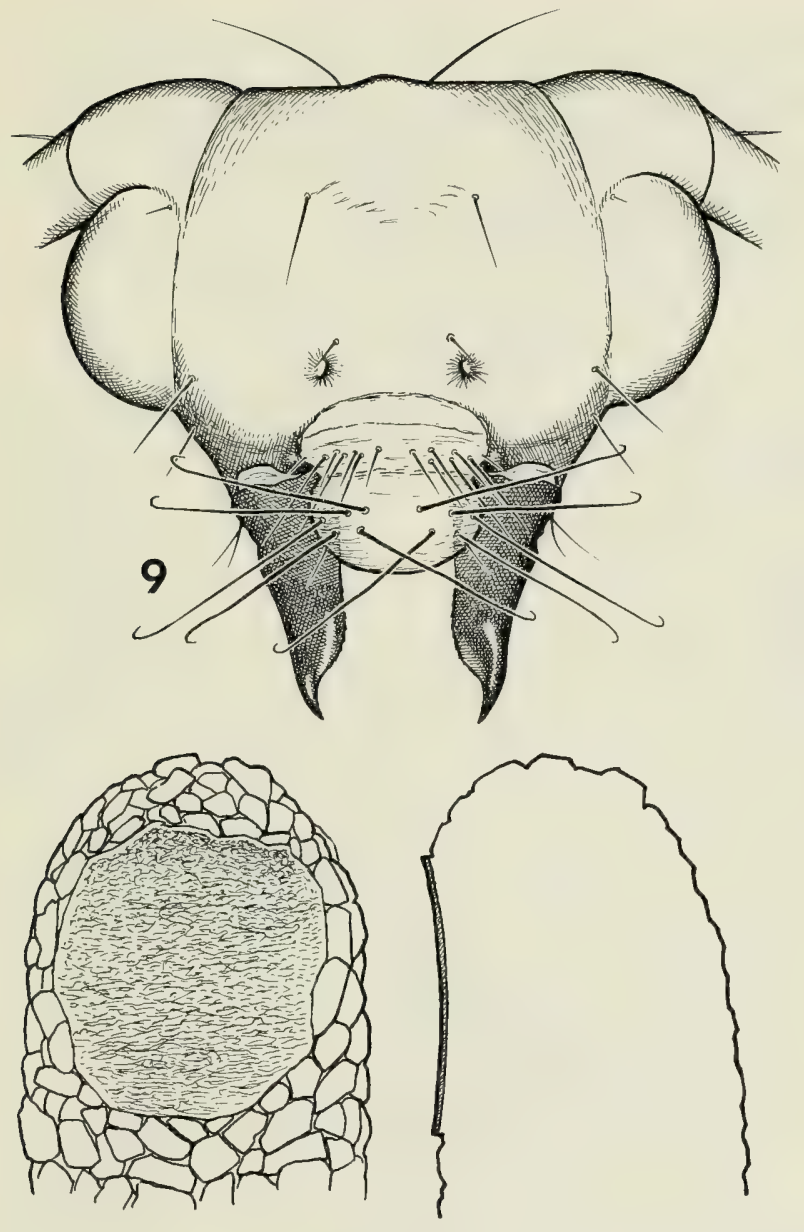

11a

$11 b$
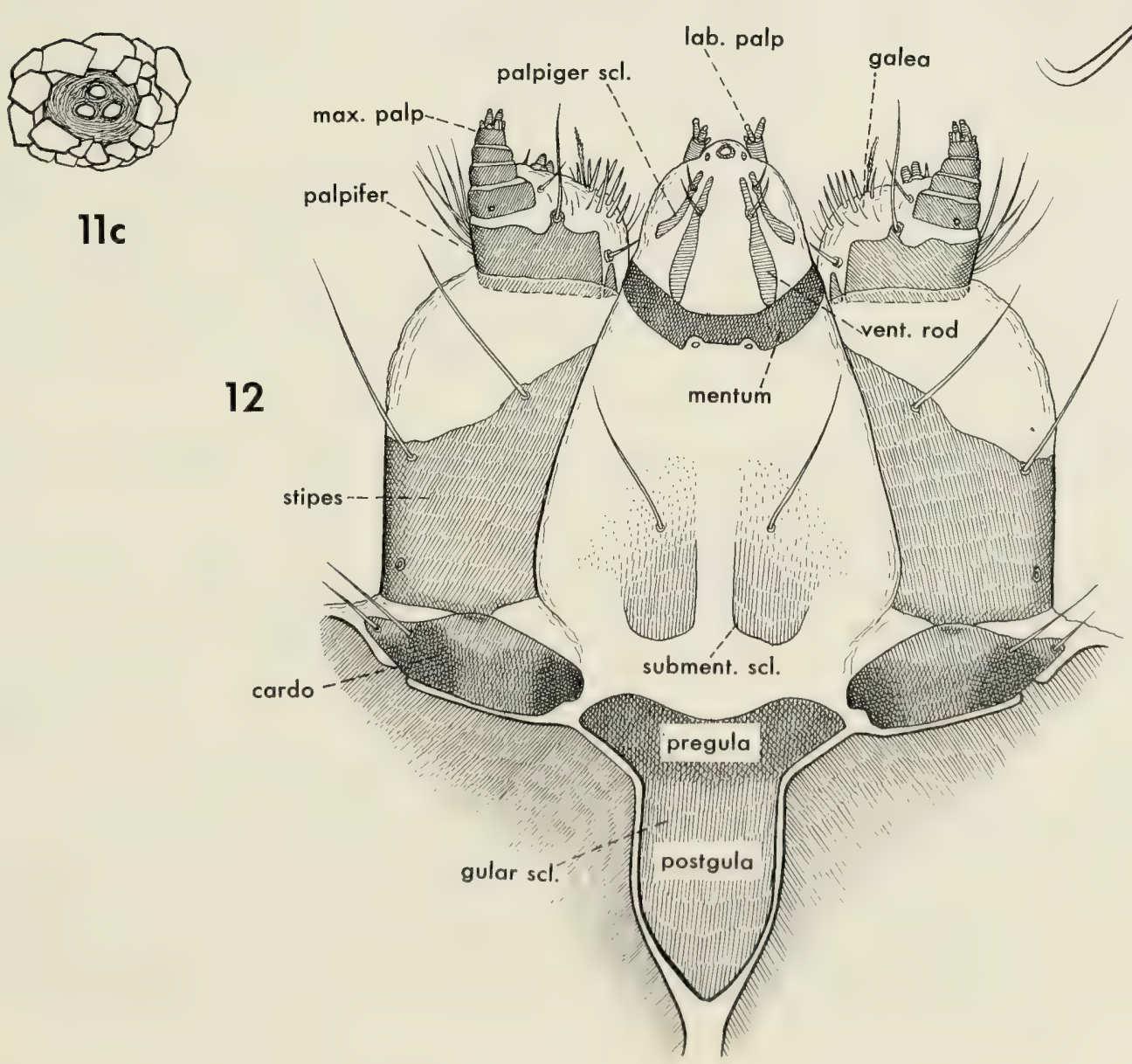
Larval case (Fig. 8) of coarse rock fragments, tapering strongly toward rear, slightly curved; anterior opening wide in relation to length, dorsal wall of case extended anterad as a hood overhanging ventral wall; posterior opening of case reduced to small circular aperture in centre.

Measurements for $A$. arizona: length of larva 6.1-7.4 mm (5); length of larval case 7.4-8.1 mm (5).

PUPA (Figs. 9 and 10). Head (Fig. 9) with mesal margin of sclerotized mandibles convex proximal to acutely pointed apex, cutting edge with minute blunt serrations; labrum with five pairs of long setae, all strongly hooked apically, seven short setae on each side in area between head and labrum. Abdomen (Fig. 10) with sclerotized plates as illustrated; single gills generally in same positions as in larva; anal processes long, slender sclerotized rods, curved laterad at tip and pointed apically, with two stout setae arising at about same point on mesal margin just before apical curvature.

Pupal case comprising larval case with dorsal wall extended as curved hood (Fig. 11a and b), placing anterior opening on ventral surface, where it is closed with a silken membrane; round posterior opening of larval case further restricted with silk to form several small perforations (Fig. 11c). Pupal case fastened to substrate by entire anterior silken disc.

The pupa of no North American species of Apatania has heretofore been described. Although the pupa of $A$. arizona is generally concordant with those of European species now known, the latter have only three small setae on each side of the base of the labrum, compared with seven in this species. Perforations for water circulation in the anterior silken membrane are present in A. muliebris (Nielsen, 1942) but are not apparent in A. arizona. Measurements for $A$. arizona: length of pupa $6.2-8.4 \mathrm{~mm} \mathrm{(8)}$; length of pupal case 6.9-9.0 $\mathrm{mm}(8)$.

TYPes. ARIZONA. Coconino Co.: Spring stream at Douglas Spring Campground, 2 miles NW Mormon Lake, 2-4 July 1966, GBW. Holotype, male (in alcohol). Paratypes $17 \sigma^{x} \sigma^{x}, 7 \%$ 우 (in alcohol); $12 \sigma^{7} \sigma^{x}, 3$ 우 (pinned). Deposited in Royal Ontario Museum and United States National Museum (Paratypes, $3 \sigma^{\top} \sigma^{\top}, 1$ 우).

LARVAL AND PUPAL MATERIAL. Same data as type series, 16 larvae, 22 pupae.

HABITAT AND BIOLOGy. Larvae and pupae of $A$. arizona were collected on rocks from a cold, slow-moving stream, approximately $1.5 \mathrm{~m}$ wide. The

Figs. 13-15 Manophylax annulatus sp. nov. adults. 13. Male genitalia: a, lateral view, $\mathrm{X} 84$; b, dorsal view, X84; c, ventral view, X84; d, phallus, lateral view, $\mathrm{X} 84$; e, phallus, ventral view, X84; inf. br., seg. $\mathrm{x}$-inferior branch, segment $\mathrm{x}$; pr. app., seg. $\mathrm{x}$ - praeanal appendage, segment $\mathrm{x}$. 14. Female genitalia: a, lateral view, $X 65$; b, ventral view, X65; sg. plate-supragenital plate. 15. Wings: a, forewing of male, X11; b, wings of female, X11. 

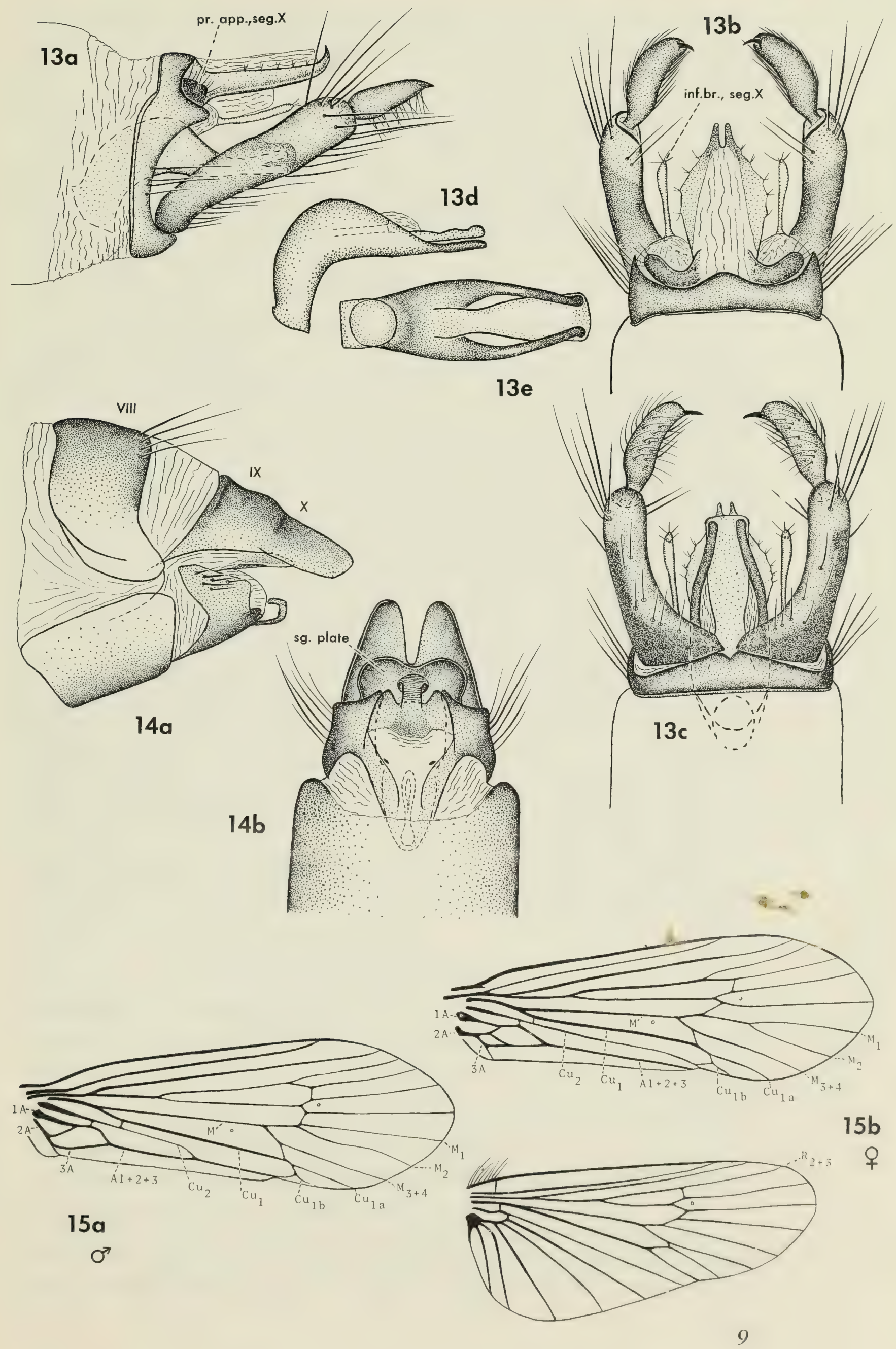
elevation of this site is approximately 6500 feet. The adults were attracted to a black light at night. Abundant in the same stream was a species of Hesperophylax.

COMMENTS. A. arizona is assigned to the malaisei subgroup on the basis of the following characters of the male: fusion of the internal branches of segment $\mathrm{x}$ to form a slender median process; terminal segment of the clasper undivided; tip of the phallus strongly spined; parameres stout and pointed, with tips crossed; a tuft of stout setae on the side of IX.

\section{Manophylax gen. nov.}

Type Species. Manophylax annulatus sp. nov.

GENERIC DIAGNOSIS. Since distinction between generic and specific characters in a monotypic genus is largely subjective, the most unusual characters are offered here.

Venation of forewing in male (Fig. 15a) distinctive in having confluence of $\mathrm{Cu}_{2}$ and $\mathrm{A} 1+2+3$ basal to normal point of confluence of these veins at wing margin, as occurring in female (Fig. 15b); hind wing in both sexes with $R_{2}$ and $R_{3}$ represented by a single vein. Male genitalia (Fig. 13) distinctive in having pair of slender appendages of segment $\mathrm{x}$ arising ventrolateral to anal opening. Female genitalia (Fig. 14) distinctive in having supragenital plate more than twice as wide as long in ventral view, terminating in two rounded anterolateral lobes and a shallow median notch.

Larva (Fig. 16) similar in general appearance to those in Apatania (Fig. 4), distinguished by the following characters: dorsum of head lacking secondary setae; on metanotum, sa 1 and sa 2 represented by well-developed sclerites (Fig. 19a); venter of first abdominal segment with widened, ringlike sclerite (Fig. 16c); claw of anal proleg with accessory tooth (Fig. 16e); larval case composed of finer rock fragmenis, more slender and with plant materials fastened to it (Fig. 20).

The prefix of this name is derived from the Greek manos-rare, and seems also appropriate because of its similarity to the name Imania. The new name is of masculine gender.

\section{Manophylax annulatus sp. nov.}

ADULT. Generally similar to species of Imania, but primarily distinguished by characters of venation and genitalia as indicated in the generic diagnosis.

Length of forewing: male, female 5.9-6.5 mm (4). Body medium brown, major setae of head and thorax generally dark, tips of some yellowish; antennae, palpi and femora medium brown, tibiae and tarsi paler.

Head with that portion of frontoclypeus mesal to anterior tentorial pits and delimited by groove in which they lie with central portion free of setae, as in Imania, but distinct from Apatania (some species at least) in which frontoclypeus uniformly covered with setae; dorsum of head with pair of large circular warts immediately behind median ocellus, pair of warts about half as large posterolateral to preceding, and pair of ovoid posterior warts. 
Thorax with mesoscutellum bearing large, yellow, median wart that has stout setae along each lateral border; mesoscutum with pair of small wartlike areas in central part; spurs $1,2,4$. Forewings with dense coating of brown hairs, without markings; venation (Fig. 15) different in each sex, unique features described under generic diagnosis. Wing-coupling mechanism (Fig. 15) consisting of approximately eight stout, non-clavate bristles at base of hind wing; ventral surface of anal margin of forewing covered with long hairs, but these do not seem (in specimens preserved in alcohol) to engage effectively with any corresponding part of hind wing.

Male Genitalia (Fig. 13). Similar generally to Imania spp. Segment IX simple, complete ring, very narrow throughout. Claspers two-segmented, basal segment long and slender in lateral view, base somewhat broadened ventrally; terminal segment finger-like in lateral view, concave mesally, flattened toward apex, and terminating in claw-like hook. Segment $\mathrm{x}$ comprising several sets of structures: median dorsal roof-like flap apparently composed of the two internal branches of segment x (sensu Schmid, 1955), connected mesally by membrane, with stout setae along lateral margins, and with distal tips of internal branches curved dorsad and separated; pair of slender, lightly sclerotized processes arising ventrolateral to internal branches, each with tuft of setae at its tip (these appear to be in same position as appendages in Moselyana comosa which are interpreted by Schmid (1968) to be inferior branches of segment $\mathrm{x}$ ); praeanal appendages not prominent, situated on each side at base of dorsal median flap, bearing many small hairs. Phallus consisting of short, tubular phallobase extended into long spatulate, somewhat troughlike, ventral process; dorsal wall of phallobase extended into pair of heavily sclerotized processes (parameres?) curving sharply ventrad below ventral process.

Female Genitalia (Fig. 14). Similar generally to Imania spp. Venter VIII separated from Ix by membrane except for narrow ventromesal band of continuous sclerotization. Lateral portions of dorsa of IX and $\mathrm{X}$ not extended ventrolaterad as a sclerotized semicylinder surrounding anal opening as in Apatania. Venter IX well developed laterally, separated from dorsum by membranous area; venter IX with quadrate median plate bearing on posterior margin a median, tongue-like lobe, transversely striated and curled strongly dorsad; this median plate abuts along darkened line of fusion on each side with venter IX, each posterolateral angle extended into small, pointed lobe. Dorsum Ix apparently fused with $\mathrm{x}$; segment $\mathrm{x}$ extended posteriorly into two elongate flaps separated by a deep median notch; supragenital plate more than twice as wide as long, bilobate and notched mesally on posterior border.

LARVA (Figs. 16-19, 24). Generally as in Apatania, but distinguished most readily by characters given in the generic diagnosis.

Length of larva 6.9-7.6 mm (5). Sclerites of head and thorax dark reddishbrown, surface of head, pro- and mesonotal plates finely pebbled.

Head more globose in dorsal view than in Apatania arizona, dorsum without secondary setae, but bases of setae 14 and 15 arising close together as in Apatania; labrum (Fig. 17) with anterolateral margins extended into 


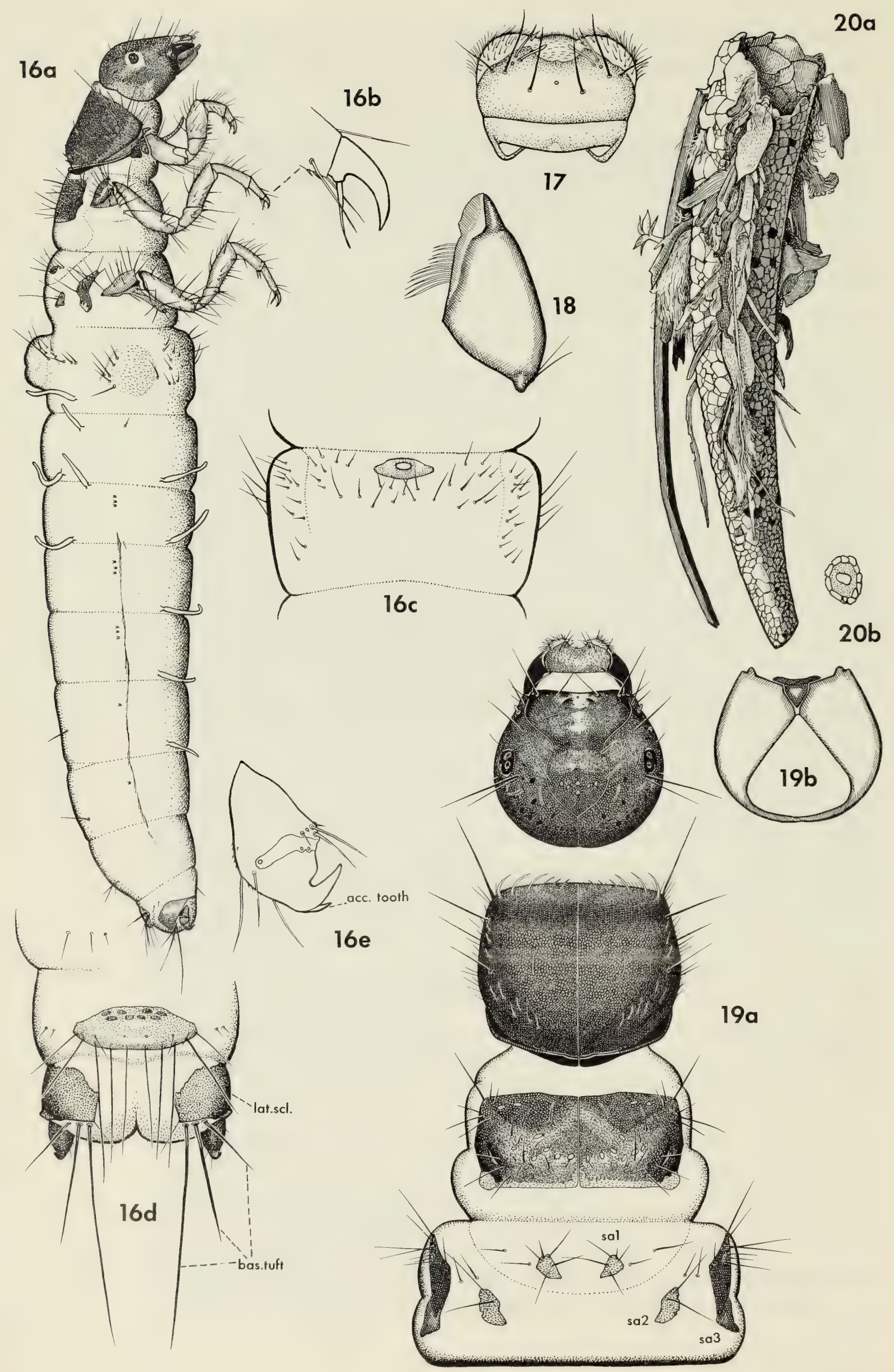


unpigmented membranous lobes as in Apatania, all six pairs of primary setae present on sclerotized area; cutting edge of mandibles (Fig. 18) entire, teeth lacking; labium (Fig. 24a) with mesal submental sclerites distinctive in comprising two large sclerites joined incompletely with a median sclerite, lateral sclerites of submentum linear; sclerite of palpiger more complete than in A arizona, extending around most of base of labial palp; maxilla (Fig. $24 \mathrm{~b}$ ) with galea flattened, although not as much as in $A$. arizona, and bearing sclerite across ventral surface of galea; gular sclerite (Fig. 19b) shorter and broader than in $A$. arizona.

Pronotum (Fig. 19a) much as in Apatania, but more robust; short, thick setae along each side and across anterior margin; prosternal horn well developed. Mesonotum with plates well developed, sa 1 represented by one or two pairs of setae. Metanotum with sa $1, s a 2$ and sa 3 represented by distinct sclerites bearing setae. Legs (Fig. 16a) with basal seta of each tarsal claw long, reaching to tip of claw (Fig. 16b); forelegs relatively shorter and tending to be more dissimilar in overall proportions from other legs than in Apatania; trochanteral brush absent from all legs.

Abdomen with single gills, arranged as illustrated (Fig. 16a); venter of segment I with anteromedian ring-like sclerite (Fig. 16c); abdominal humps well developed, 13-16 (5) short setae between median hump and each lateral hump, 59-60 (5) setae on ventral surface; venters III to VII inclusive with ovoid scleritized ring; dorsal sclerite of IX wide in dorsal view (Fig. 16d), greater than half width of segment, bearing 12-16 (5) rather uniformly long setae, not crowded with small setae as in Apatania; claw of anal proleg with well-developed accessory tooth (Fig. 16e); lateral sclerite of anal proleg larger than in Apatania, in dorsal view extending more than half the distance to anal fissure on midline (Fig. 16d); basal tuft with three straight, stout setae, inner seta longer than others (Fig. 16d).

Larval case (Fig. 20) basically of fine rock fragments, finer than in case of $A$ arizona, tapered posteriorly and slightly curved; case more slender than in A. arizona; small twigs and leaf fragments fastened to dorsolateral surfaces of case; patches of filamentous algae appear to be growing on all cases. Length of larval cases 8.0-9.6 mm (5).

PUPA (Figs. 21-23). Generally similar to pupae of Apatania, distinguished primarily by the shape of the anal processes.

Length of pupa 6.4-7.4 mm (2). Head (Fig. 21) with mesal margin of sclerotized mandibles convex proximal to acutely pointed apex, cutting edge

Figs. 16-20 Manophylax annulatus sp. nov. larva. 16. Larva: a, lateral view, X20; b, mesotarsal claw, X58; c, first abdominal segment, ventral view, X26; d, ninth abdominal segment and anal prolegs, dorsal view, X46; e, claw of right anal proleg, X185; acc. tooth-accessory tooth; bas. tuft-basal tuft; lat. scl.-lateral sclerite. 17. Labrum, dorsal view, X71. 18. Mandible, left side, ventral view, X110, 19. Head and thorax: a, dorsal view, X30; b, head capsule, ventral view, X30; sa 1, 2, 3-setal area 1, etc. 20. Larval case: a, ventrolateral view, $\mathrm{X} 10 ; \mathrm{b}$, posterior end of larval case, facial view, $\mathrm{X} 10$. 

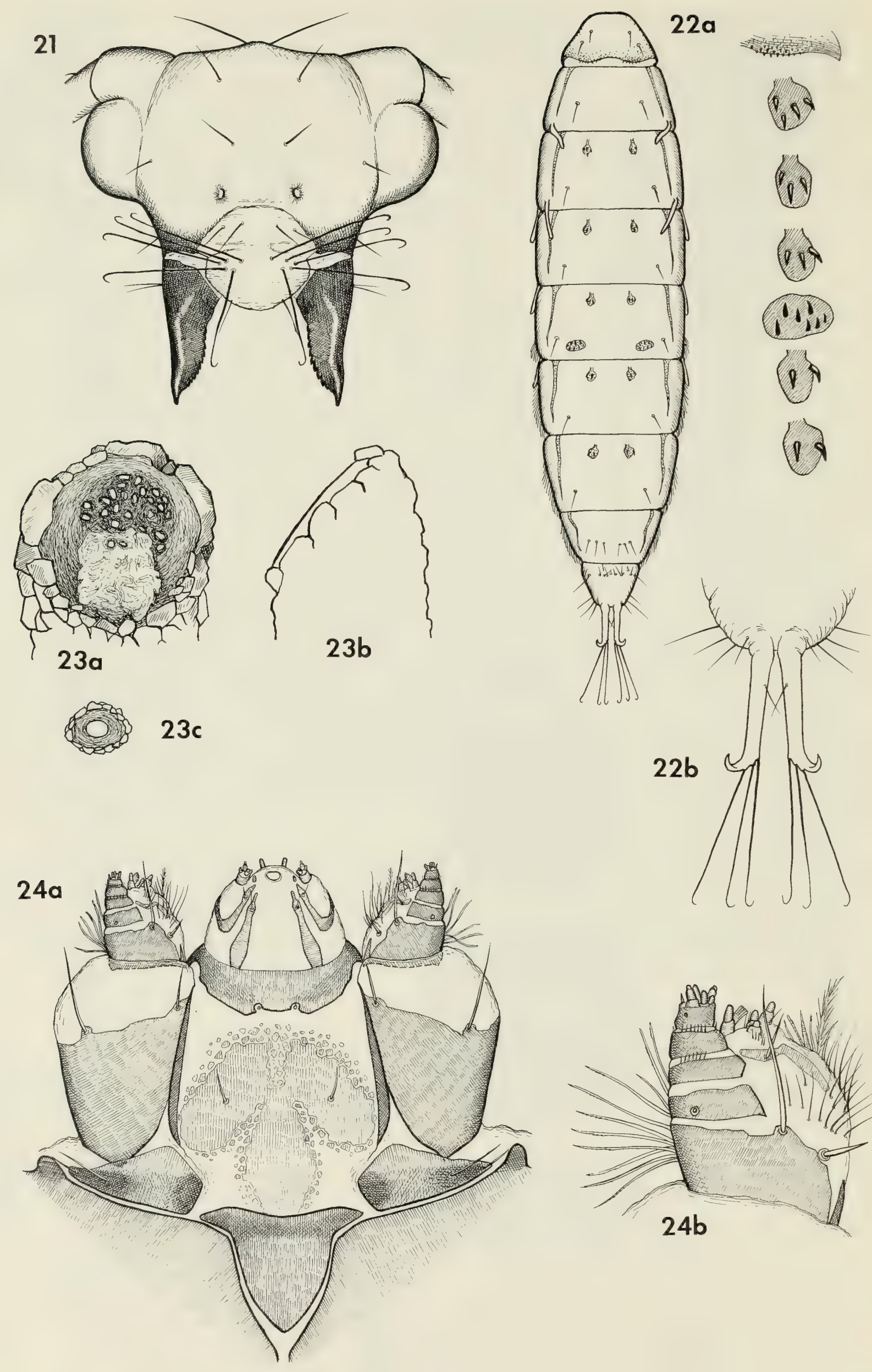
with small blunt teeth; labrum with five pairs of stout setae, all strongly hooked apically, two shorter setae on each side at base of labrum. Abdomen (Fig. 22) with sclerotized plates as illustrated; short, single gills in posterodorsal position on segments II and III, and in posteroventral positions on segments III, IV and v; anal processes long, stout, sclerotized rods, stouter than in $A$. arizona, curved laterad near distal end, tip an unturned point, three stout, hooked setae arising from mesal face of curve.

Pupal case similar in every respect to larval case; anterior end closed by dense silken membrane with central perforate area (Fig. 23a and b) fastened over oblique anterior rim of case; posterior opening apparently unmodified from the larval case (Fig. 23c). Length of pupal case 8.3-10.1 mm (5).

TYPES. IDAHO. Idaho Co.: NE of Lowell, small stream crossing Route 12 between Holly Creek and Stanley Creek, 24 June 1968, G.B.W., T. Yamamoto, I. M. Smith. Holotype, male (in alcohol). Paratypes (in alcohol) $2 \sigma^{7} \sigma^{7}, 1$ \% , same data as preceding but collected as pupa and reared. All types deposited in Royal Ontario Museum.

Larval AND PUPAl MAterial. Same data as type series, 24 larvae, 2 pupae.

HABitat. Larvae and pupae were taken in a small stream $30-45 \mathrm{~cm}$ wide, cascading over boulders down a steep hillside. Larvae were found on flat rocks in a thin film of flowing water. Pupal cases, mostly empty, were found on the damp surfaces of rocks along the edge of the stream.

COMmEnTs. $M$. annulatus exhibits two characteristics that are unusual, if not unique, in the Limnephilidae: the point of confluence of $\mathrm{Cu}_{2}$, with $\mathrm{A} 1+2+3$ in the forewing of the male, as described under the generic diagnosis; and the thickened, ring-like sclerite on the venter of the first abdominal segment of the larva, to which the species name refers.

Manophylax has more general similarity to Imania than to any other genus now known. The male and female genitalia show basic structural similarity, although this could reflect only a preponderance of ancestral characters in each. But, for the larvae, analysis of derived characters offered later in this paper indicates that Manophylax and Imania are interrelated. Some features are, however, discordant between these two genera. The gular sclerite is not T-shaped in Manophylax (Fig. 19b) as it is in Imania (Fig. 29). Arrangement of setae on segments IX and $\mathrm{x}$ of the larvae (cf. Figs. 16d, 28c) is different in the two genera. In the pupa the setae on the labrum are hooked apically in Manophylax (Fig. 21) and in the Apataniinae (Fig. 9), but straight in Imania (Fig. 33).

Figs. 21-24 Manophylax annulatus sp. nov. pupa and larva. 21. Head of pupa, facial view, X45. 22. Pupal abdomen: a, dorsal view, X19, with sclerotized plates enlarged; b, anal processes, dorsal view, X40. 23. Pupal case: a, anterior end, facial view, X14; b, same, profile view, X14; c, posterior end, X14. 24. Maxillae and labium of larva: a, ventral view, X143; b, apical portion of left maxilla enlarged, ventral view, X388. 


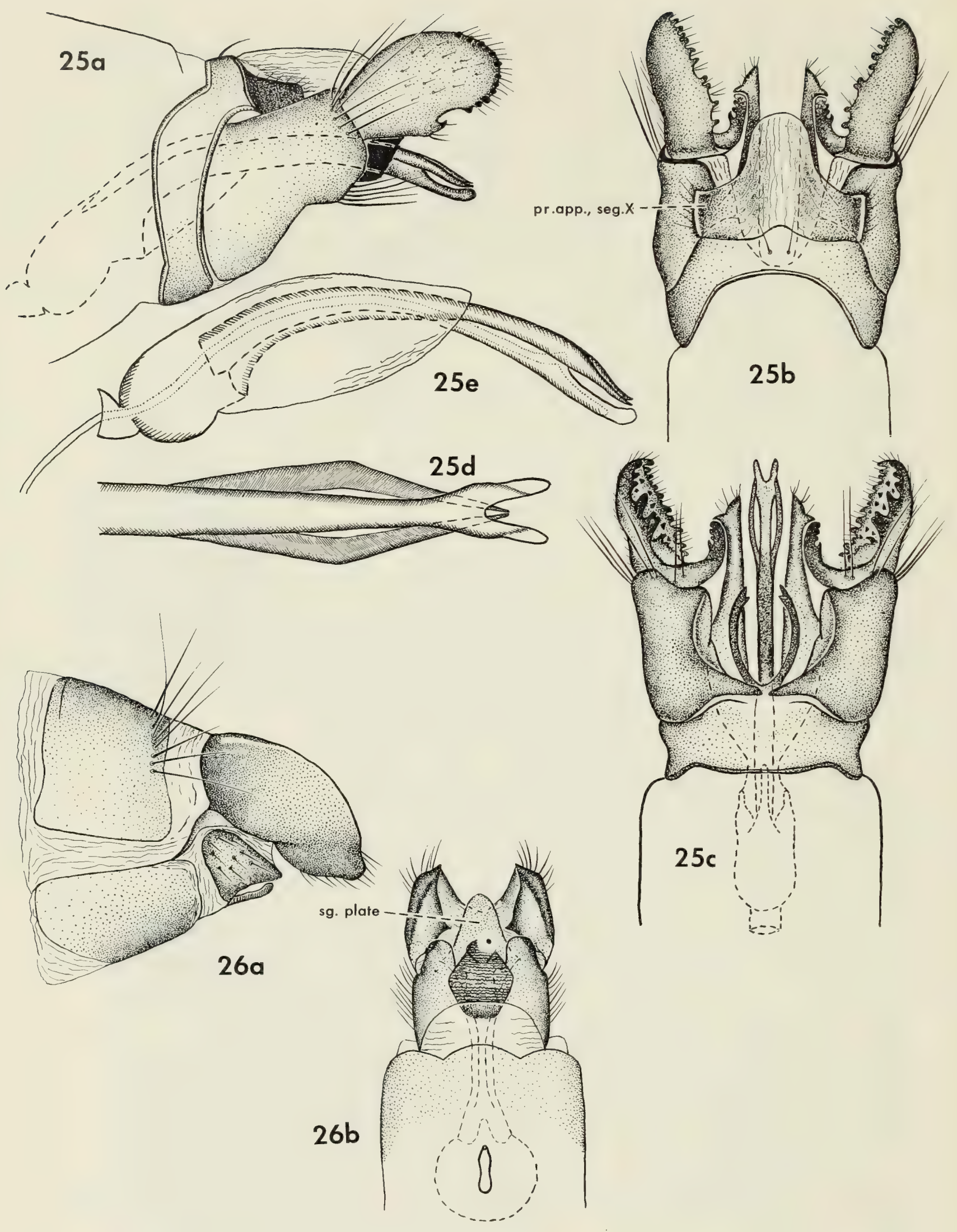

Figs. 25-26 Imania scotti sp. nov. adults. 25. Male genitalia: a, lateral view, X54; b, dorsal view, X54; c, ventral view, X54; d, phallus, ventral view, X54; e, phallus, lateral view, X54; pr. app., seg X-praeanal appendage, segment X. 26. Female genitalia: a, lateral view, X50; b, ventral view, X50; sg. plate-supragenital plate. 
This species is a member of the tripunctata group, and can be differentiated in both sexes by characters of the genitalia.

ADULT. Length of forewing: male 7.7-8.1 mm (4), female 7.7-9.0 mm (5). General structure typical for the genus and for the tripunctata group; dark brown in colour, forewings covered with uniformly dark brown hairs. Venation similar in the two sexes, essentially as illustrated for I. bifosa Ross by Schmid (1955, fig. 15). Wing-coupling mechanism consisting of approximately eight stout, non-clavate, bristles at base of hind wing, and line of short, stout, hooked setae along costal margin of hind wing which engage upon long hairs arising from anal margin of forewing, much as illustrated for Lepania cascada by Wiggins (1973, fig. 21 ).

Male Genitalia (Fig. 25). Not similar to any other species; readily identified by the ovoid lateral outline of the terminal segment of the clasper, compared with the pincer-like lateral aspect of this segment in other species of the group.

Segment IX uniformly narrow throughout, as in other members of tripunctata group. Claspers with basal segments united ventrobasally, bearing at this point a pair of slender curved processes, each one notched apically; terminal segment ovoid and broadly rounded laterally, almost completely concealing in this view a stout, dentate, ventromesal process; mesal surface of terminal segment beset with stout denticles. Segment $\mathrm{x}$ consisting of dorsal semimembranous, roof-like plate overhanging pair of stout, heavily sclerotized, ventral processes, each terminating with apical and lateral points, and each process possibly representing fused internal and external branches of segment X (sensu Schmid, 1955); at base of segment X, pair of short angulate lobes bearing fine setae probably represents praeanal appendages. Phallus different from that in any other species of group, if not genus, in having pair of slender parameres fused dorsally to an arched, trough-like aedeagus; near apex of phallus these arms separate from aedeagus, which itself terminates in spoon-like concavity with deep median apical notch; in other species of Imania phallus bears apical aedeagus (sensu Nielsen, 1957), proximal to which arises pair of sclerotized arms that are not fused along their length (Ross, 1950, figs. 1-6).

Female Genitalia (Fig. 26). Resembles in general structure females of Manophylax (Fig. 14) and Moselyana (Fig. 38) but not of the Apataniinae. Generally similar in structure to those of other females known in the tripunctata group, I. tripunctata and I. gnathos (Ross, 1950, figs. 7, 8) with a char¿ teristically long vagina, but distinguished by a broad median notch in the posterior border of segment $\mathrm{X}$.

Dorsa of IX and $\mathrm{X}$ apparently fused with no line of separation; venter IX represented by pair of lateral sclerites, separated on midventral line by angular, transversely-striated plate. 


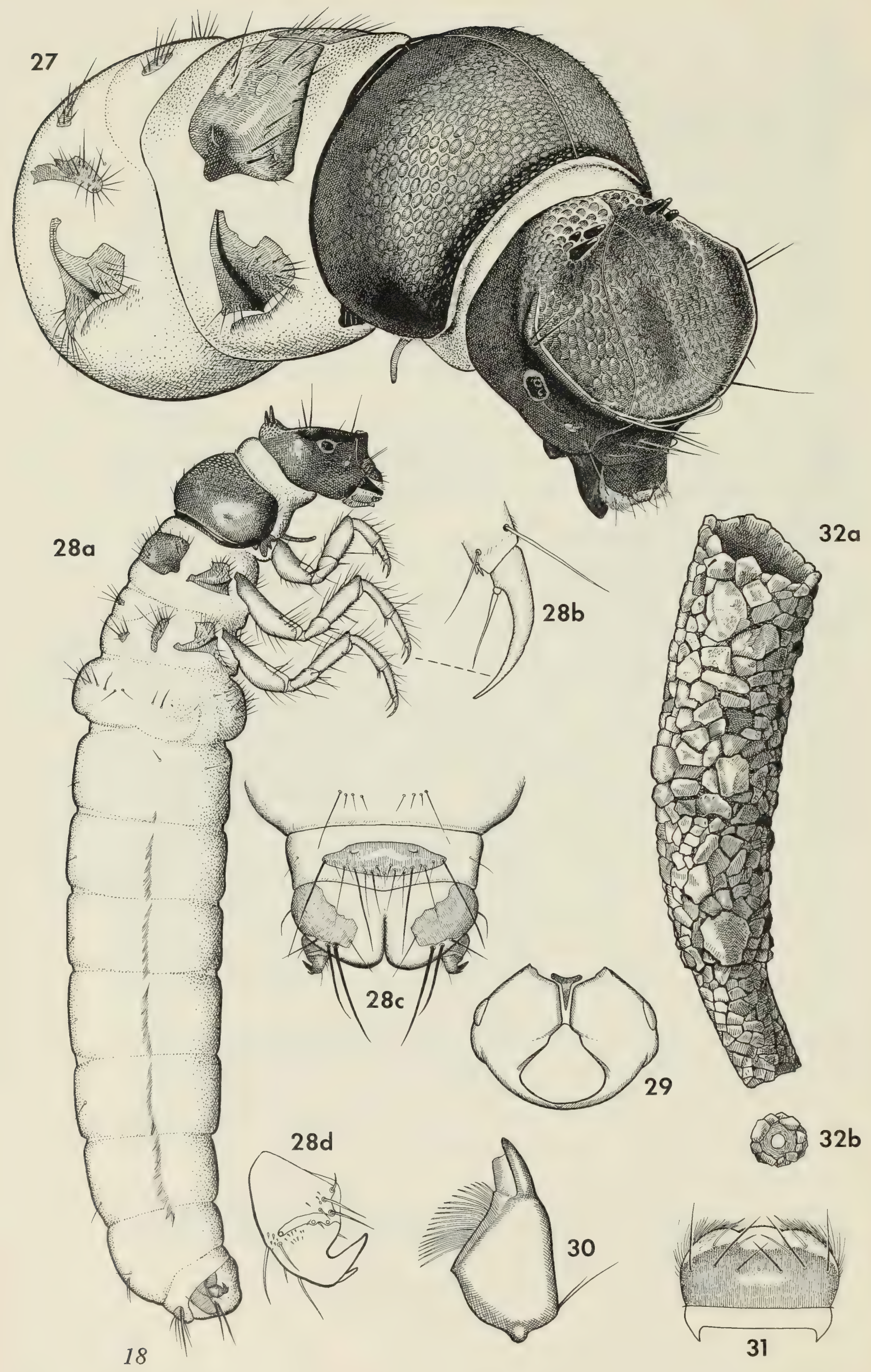


LARVA (Figs. 27-31, 36). Generally similar to other larvae in this genus, but distinguished primarily by the prominent horns on the head.

Length of larva 7.0-8.0 mm (5). Head with very prominent dorsal carina arising just behind eyes and extending completely around anterolateral margin; two clusters of three or four prominent, straight horns arise from raised posterodorsal area of head; central part of head concave, with coarse granulations extending posterior to horns; head capsule in dorsal view wider than long, broadly elliptical; secondary setae absent; primary setae reduced, but what appear to be setae 14 and 15 arise close together as in Apatania. Mandibles (Fig. 30) with cutting edge entire, teeth lacking; gular sclerite (Fig. 29) T-shaped, lateral margins of postgula linear; maximum width of postgula less than one-half maximum width of pregula; labrum (Fig. 31) with anterolateral margins membranous as in Apatania. Labium (Fig. 36) with both mesal and lateral submental sclerites; sclerite of palpiger extending somewhat more than half way around base of labial palp. Maxilla (Fig. 36) with galea flattened and dome-like.

Pronotum wide, inflated and strongly convex, surface coarsely granulate, anterodorsal area with short golden pubescence; prosternal horn well developed. Mesonotum short and wide, shorter mesally than laterally. Metanotum with all three primary setal areas represented by well-developed sclerites. Legs as illustrated (Fig. 28a); tarsal claws somewhat longer and more slender than in Apatania, but with basal seta reaching almost to tip of claw (Fig. $28 \mathrm{~b})$; trochanteral brushes absent from all legs.

Abdomen lacking gills; first abdominal segment with 15-19 (5) dark setae between dorsal hump and each lateral hump, and 68-76 (5) dark setae on venter; venters II to VII inclusive each with an ovoid sclerotized ring; posterodorsal sclerite of IX with four major setae and 15-18 (5) minor setae; claw of anal proleg with accessory tooth (Fig. 28d); basal tuft of anal proleg with three stout setae, lateral seta less than half as long as two mesal setae (Fig. 28c).

Larval case (Fig. 32) of small stones, without lateral ridges, but basal quarter sharply constricted from remainder; posterior end reduced with silk to a round, central hole; length of larval case up to 8.1-9.3 $\mathrm{mm}$ (5).

PUPA (Figs. 33, 34). Length of pupa 7.7-8.6 mm (5). Mandibles (Fig. 33) with cutting edge convex proximal to apex, lacking dentations; labrum with all major setae lacking apical hook of Apatania and Manophylax. Abdomen without gills; anal processes heavily sclerotized and stout, not slender as in many genera of family, and bearing three stout setae along posteromesal face of terminal enlargement; some variation seen in sclerotized anal processes, stouter than illustrated in some pupae.

Figs. 27-32 Imania scotti sp. nov. larva. 27. Head and thorax, frontolateral view, X42. 28. Larva: a, lateral view, X18; b, mesotarsal claw, X140; c, ninth abdominal segment and anal prolegs, dorsal view, X42; d, claw of right anal proleg, X133. 29. Head capsule, ventral view, X24. 30. Mandible, left side, ventral view, X119. 31. Labrum, dorsal view, X64. 32. Larval case: a, ventrolateral view, X10; b, posterior end, facial view, X10. 


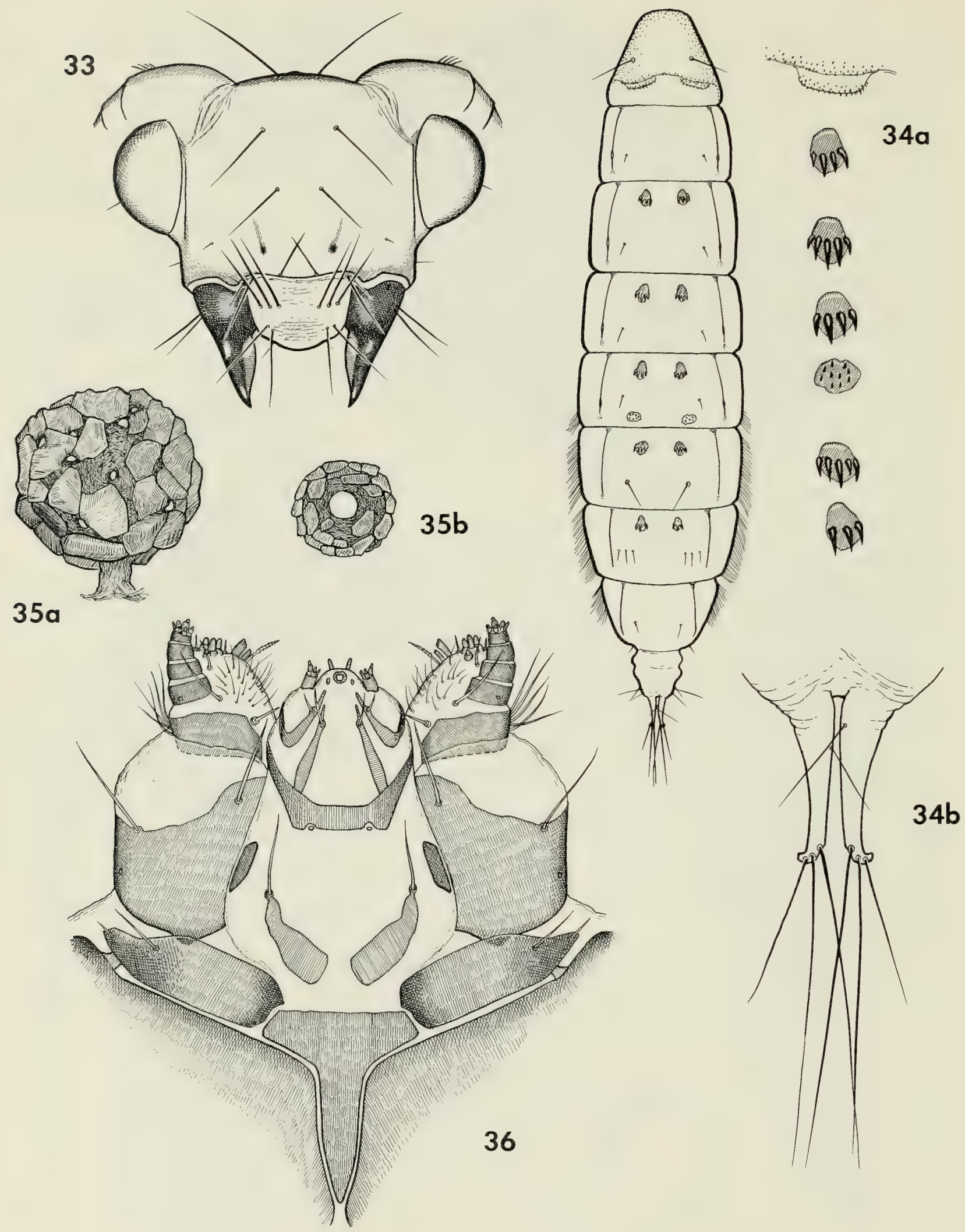

Figs. 33-36 Imania scotti sp. nov. pupa and larva. 33. Head of pupa, facial view, X42. 34. Pupal abdomen: a, dorsal view, X13, with sclerotized plates enlarged; b, anal processes, dorsal view, X92. 35. Pupal case: a, anterior end, facial view, X14; b, posterior end, facial view, X14. 36. Maxillae and labium of larva, X180. 
Pupal case similar to larval case in every respect, retaining characteristic constricted basal portion; silken closure membrane of anterior opening (Fig. 35a) with small holes scattered over entire surface, some small stones fastened to silk; posterior opening (Fig. 35b) apparently not modified from condition in larval case. Length of pupal case 10.1-12.2 mm (5).

TYPES. OREGON. Mt. Hood, alpine stream crossing paved road between Government Camp and Timberline Lodge at a point 3.3 miles below Timberline Lodge; elevation approximately $4200 \mathrm{ft}$; all collected by G.B.W. and R. S. Scott. Holotype, male, data as above, reared by N. H. Anderson from pupae collected 20 April 1964. Paratypes, same data as holotype, $4 \sigma^{7} \sigma^{7}$, 4 ㅇ ; 16 July 1963, 5 ㅇ , G.B.W. Deposited in Royal Ontario Museum and United States National Museum (Paratype $\sigma^{\top}$, $\%$ ); all preserved in alcohol.

LARVAL AND PUPAL MATERIAL. OREGON. Mt. Hood, alpine stream crossing paved $\mathrm{rd}$ between Government Camp and Timberline Lodge at a point 3.3 mi below Timberline Lodge, elev. 4200 ft, 18-20 April 1964, G.B.W., R. S. Scott, many pupae, 2 larvae; as above, 28-29 Sept. 1966, G.B.W., T. Yamamoto, A. Odum, many larvae, 1 pupa; as above, 11-12 June 1967, T. Yamamoto, many larvae; as above, 19 June 1968, G.B.W., T. Yamamoto, I. M. Smith, many larvae, 10 prepupae; as above, 8 June 1969, Rom field party, 4 larvae, 2 pupae; South Fork Iron Creek, 29 Sept. 1966, G.B.W., T. Yamamoto, A. Odum, 8 larvae, 8 prepupae; as above, 11 June 1967, T. Yamamoto, many larvae.

HABITAT AND BIOLOGY. The stream on the Timberline Lodge road from which most of the material was collected is about $2 \mathrm{~m}$ in width and falls rapidly over a boulder-strewn course. The water is clear and cold, temperature in July $2{ }^{\circ} \mathrm{C}\left(36^{\circ} \mathrm{F}\right)$, and presumably comes from springs supplied by the permanent snowfields around the summit of Mt. Hood. Rocks in the stream bear dense growths of a wiry moss, and at the base of the moss fronds larvae of Imania scotti were found. Pupal cases were fastened to the moss. Life history data compiled from collections indicate that two years are required for a complete cycle. Prepupae occur in collections as early as June, are still present in September, but have changed to pupae by the following April. Larvae of at least two other species of Imania were taken from this same locality, one of which has proven to be I. cidoipes Schmid.

COMMENTS. A sharp carina on the larval head appears to be a secondary specialization that recurs in various groups of case-making Trichoptera. In living larvae of Imania the head is borne at an angle to the thorax such that the carina aligns with the pronotal plate to form an armoured closure to the anterior opening of the larval case.

In our field work, associations have been established for two additional species of Imania, and many series of larvae have been taken from cold spring streams at high elevations in western North America. All other larvae of Imania known to me lack the horns on the head that are characteristic of 

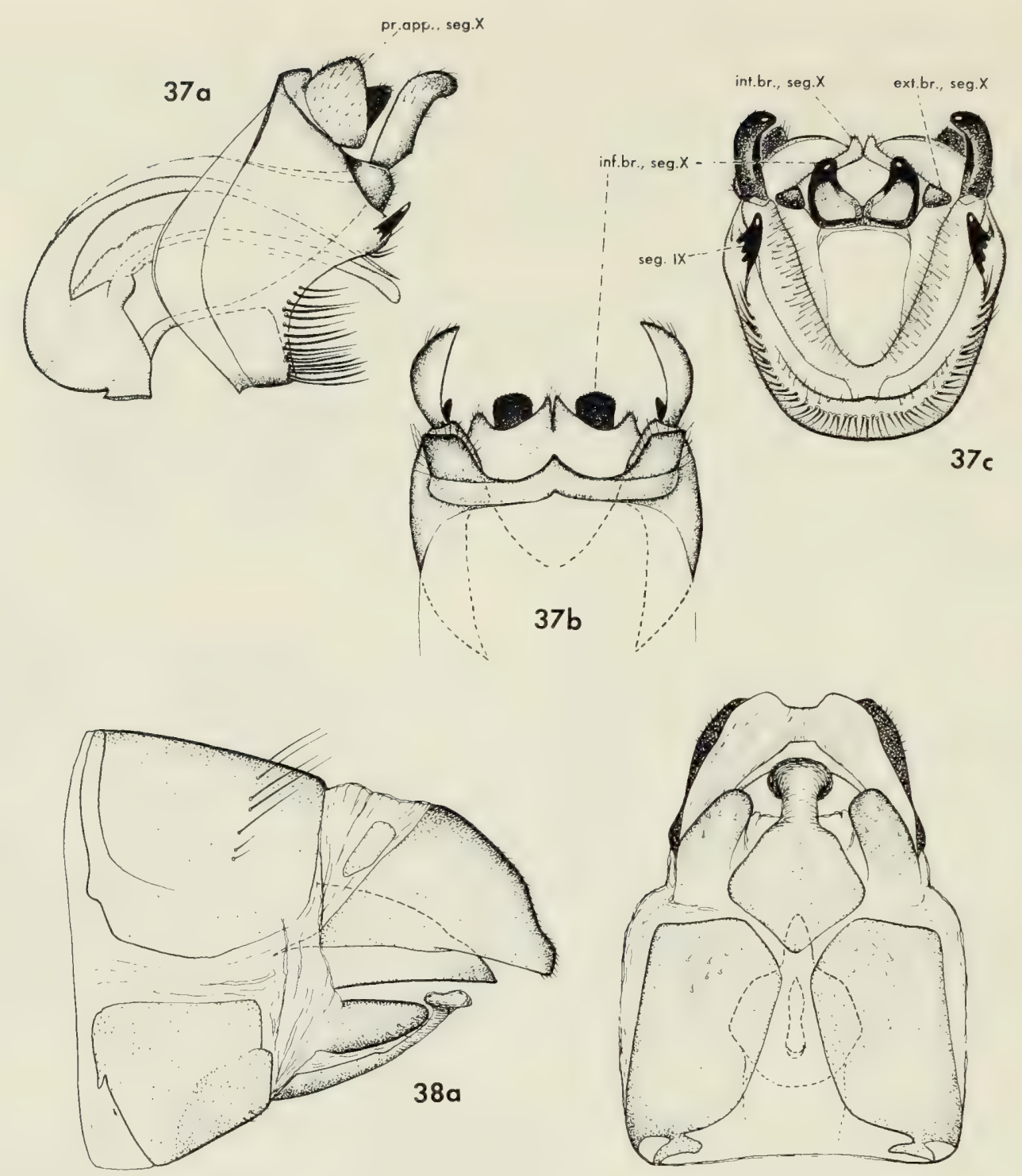

$38 \mathrm{~b}$

Figs. 37-38 Moselyana comosa Denning adults. 37. Male genitalia: a, lateral view, $\mathrm{X} 62$; b, dorsal view, X62; c, caudal view, X62; ext. br., seg. X-external branch, segment $\mathrm{x}$; inf. br., seg. $\mathrm{x}$-inferior branch, segment $\mathrm{x}$; int. br., seg. $\mathrm{X}$-internal branch, segment $\mathrm{x}$; pr. app., seg. $\mathrm{x}$-praeanal appendage, segment x; seg. IX-segment IX. 38. Female genitalia: a, lateral view, $\mathrm{X} 60$; b, ventral view, $\mathrm{X} 60$.

I. scotti, but do have the pronounced carina that appears to be a consistent character throughout this genus. Some species differ, however, in such characters as the depth of the dorsal concavity of the head. The larval case of I. scotti is thus far unique in having a basal constriction; all others known to me are uniformly tapered, and in at least one other species, I. cidoipes Schmid, the case bears a low ridge of stones along each side.

The larva described as "Limnephilid Genus D" by Ross (1959, p. 1044) and by Flint $(1960$, p. 32) probably belongs to Imania. The larva of an Asiatic species 1 . sajanensis Levanidova has also been described (Levanidova, 1967), and appears to be consistent in structure and habitat with the North American species. 
This species is named after the late Mr. Robert S. Scott, my companion on the field expedition in which identity of these remarkable larvae was established. The genus Imania takes its name from the Iman River in the South Ussuri region of the U.S.S.R., along the upper reaches of which adults of the type species I. sichotalinensis (Martynov, 1935) were first collected.

\section{Moselyana comosa Denning}

Moselyana comosa Denning, 1949, p. 89, fig. 2.

Moselyella comosa. Schmid, 1968, p. 682, figs. 17-22.

This is the only species in the genus, and its larva and pupa were previously unknown.

ADULT. Most descriptive details of the adults of this species are available in the references given above, and are not repeated, although male and female genitalia are illustrated here (Figs. 37 and 38 resp.) to facilitate comparisons made in this paper. Some additional descriptive details follow.

Length of forewing, male 5.7-6.3 mm (10), female 4.8-5.5 mm (10). Wing-coupling mechanism consisting of three or four stout, non-clavate bristles at base of hind wing; short setae on under side of forewing engage with setae along costal edge of hind wing.

LARVA (Figs. 39-40, 47). Length of larva 6.2-6.9 mm (10). Sclerites of head and thorax brownish-red. Head (Fig. 40a) rounded in dorsal view; dorsum of head with a few secondary setae on posterior part of frontoclypeus, setae 14 and 15 not arising close together, the distance between their bases approximating diameter of eye; labrum (Fig. 41) with anterolateral margins unpigmented, but apparently sclerotized and not extended as semimembranous lobes; seta 4 of labrum broad at apex; mandibles (Fig. 42) with cutting edge subdivided into separate teeth, stout brush of serrate hairs arising from mesal edge of each mandible; labium (Fig. 47) with mesal submental sclerites fused to form single, median sclerite, lateral submental sclerites almost touching tip of median sclerite; gular sclerite (Fig. 40b) not T-shaped as in Imania, with margins of postgula curved, not linear.

Pronotum (Fig. 40a) unusually broad in dorsal view, wider than long, surface pebbled; prosternal horn well developed, slightly longer than anterior coxa. Mesonotum broad, plates extending to and slightly overlapping mesopleura, posterior margin thickened and darkened. Metanotum with three primary setal-bearing sclerites lightly sclerotized and pigmented, many setae scattered over membrane between scletrites. Legs (Fig. 39a) with second and third femora bearing six or seven stout ventral or subventral setae; trochanter of first legs with brush of hairs; basal seta of tarsal claws much shorter than claw (Fig. 39b).

Abdomen with humps of segment I well developed, lateral humps with minute denticles, many small setae between each lateral hump and median hump, many small setae on ventral surface of segment I; abdominal gills absent; ventral sclerotized ring on segments II-VII inclusive; segment VIII 


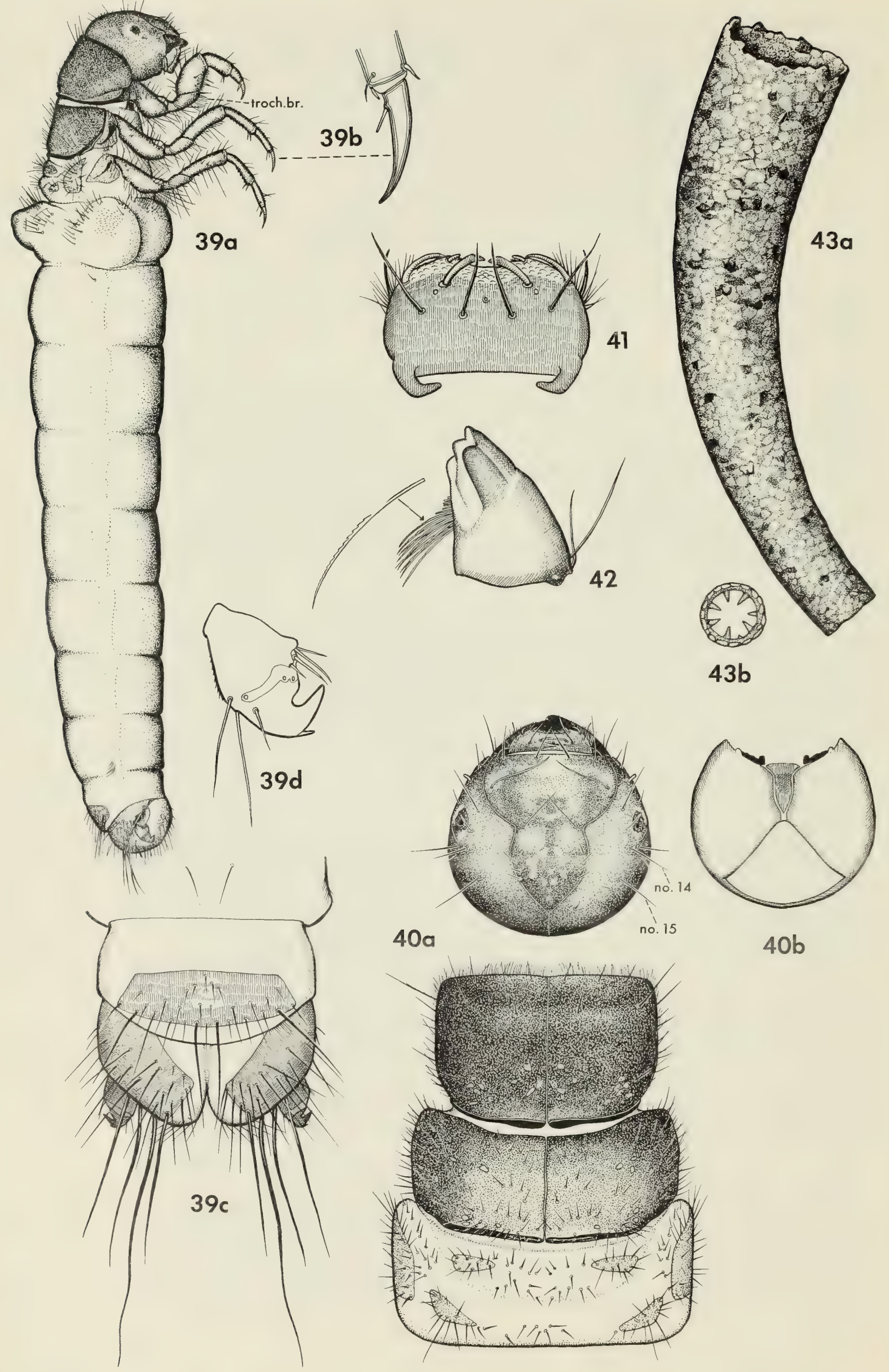


with posterolateral brush of fine hairs; posterodorsal sclerite of segment IX with two pairs of stout setae along posterior margin, and 26-37 (10) slender setae; anal proleg (Fig. 39c) with four stout setae in basal tuft, lateral sclerite with many fine setae, claw with accessory tooth; 35-44 (5) setae on ventral surface of anal proleg on each side of anal opening.

Larval case (Fig. 43) of fine rock fragments, strongly tapered and curved, exterior very smooth because covered with silken secretion; posterior opening restricted with several triangular projections of silken secretion fastened to the inner rim and directed toward the centre of the opening. Length of larval case 7.4-8.1 $\mathrm{mm}(10)$.

PUPA (Figs. 44 and 45). Length of pupa 6.8-7.0 mm (3). Head (Fig. 44) with cutting edge of mandibles minutely serrate but slightly concave, thus differing from the convex outline of the cutting edge in Imania, Manophylax and Apatania; labrum with five pairs of major setae, all hooked apically. Abdomen with sclerotized plates as illustrated (Fig. 45); gills absent; anal processes (Fig. 45b) long and slender, the apex of each with cluster of short, stout spines.

Pupal case with anterior opening closed by uniform silken membrane (Fig. 46a), an indication of some small holes around periphery; posterior opening of larval case further restricted with silk to form membrane with small performations (Fig. 46b). Length of pupal case 6.9-8.2 mm (5).

MAterial EXAmined. OREGON. Benton Co.: Marys Peak, seepage area beside Parker Creek at Marys Peak Campground, 14-15 June 1968, G.B.W., T. Yamamoto, I. M. Smith, many larvae, 1 pupa; as above, 6 June 1969, Roм Field Party (690050), many larvae, 4 pupae, many $\sigma^{7} \sigma^{\Upsilon}$, many ㅇ \& ; Marys Peak, Parker Creek, 14 June 1967, T. Yamamoto, $6 \sigma^{\top} \sigma^{\top}, 1$ \%; Mt. Hood, tributary of Salmon R., 23 July 1955, S. G. Jewett Jr., 1 ठ ; ; Mt. Hood, seepage area at Still Creek Forest Camp, near Government Camp, 20 June 1968, G.B.W., T. Yamamoto, I. M. Smith, 1 ơ'.

HABITAT AND BIOLOGY. Adults of $M$. comosa were found in June flying in numbers over a spring seepage area some $2 \mathrm{~m}$ from Parker Creek..The seepage was coming out of the ground at the top of an inclined bank covered with a dense growth of moss clumps and Equisetum sp. Seepage water overflowed from small depressions in the soil, dripped progressively to lower levels, and ultimately to the stream. The soil of the entire area was saturated with

Figs. 39-43 Moselyana comosa Denning larva. 39. Larva: a, lateral view, X21; b, mesotarsal claw, X136; c, ninth abdominal segment and anal prolegs, dorsal view, X29; d, claw of right anal proleg, X171; troch. br.-trochanteral brush. 40. Head and thorax: a, dorsal view, X50; b, head capsule, ventral view, X50; no. 14 , no. 15 -setae 14 and 15.41. Labrum, dorsal view, X118. 42. Mandible, left side, ventral view, X93, with one hair of mesal tuft enlarged. 43. Larval case: a, lateral view, X14; b, posterior end, facial view, $\mathrm{X} 14$. 

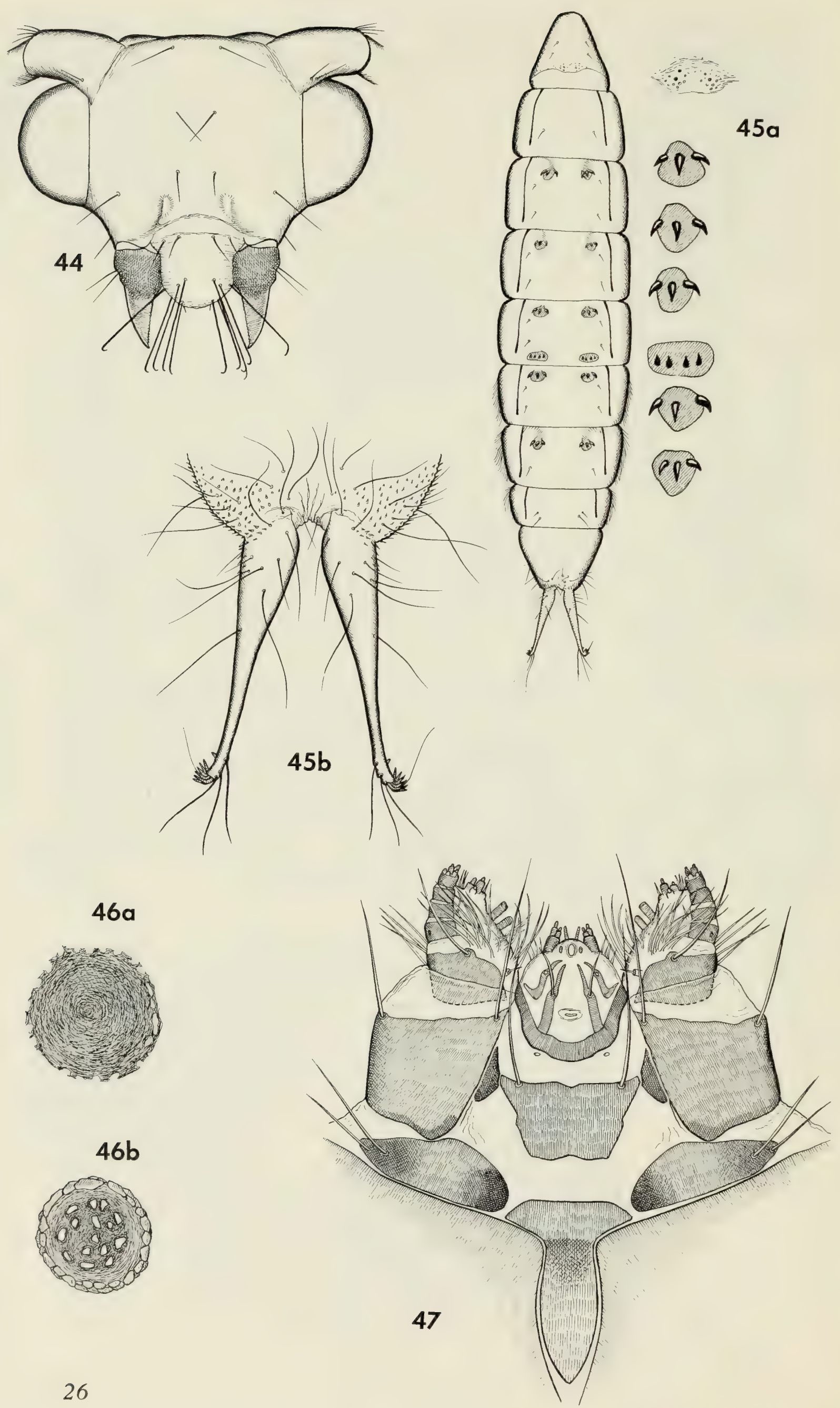
water. Larvae and pupae were collected in muck taken from the seepage area, but were not found in the stream itself.

Comments. As pointed out by Schmid (1968), Moselyana comosa is unusual in having a pair of appendages of segment x (Fig. 37) arising ventrolateral to the anal opening, and interpreted by him as inferior branches of $\mathrm{x}$. Apparently these appendages are not present in the Apataniinae. In the male of Manophylax annulatus, however, a pair of slender processes of segment $\mathrm{x}$, arising ventrolateral to the anus (Fig. 13) could be homologous with the inferior branches of $\mathrm{x}$ in M. comosa. In Imania scotti (Fig. 25) there is a pair of processes arising ventrolateral to the body of $\mathrm{x}$ which is unusual for that genus. Because these processes have a heavily sclerotized ventral connection with the base of segment $\mathrm{x}$, they seem best interpreted as external and/or internal branches of $\mathrm{x}$, although the possibility remains that in all three genera these processes might be homologous. The male genitalia of $M$. comosa show an unusual development in a broadening of the posterolateral margin of IX to encompass the basal segment of the clasper (Fig. 37).

As shown later in this paper in an analysis of larval characters, Moselyana is widely separated from Imania, Manophylax, and Apatania through several characters that are generally diagnostic for the Apataniinae and related groups. These include mandibles with teeth, a completely sclerotized labrum, and short basal setae on the tarsal claws.

\section{Systematic Considerations}

Although Apatania arizona is largely concordant in larval, pupal, and adult stages with the subfamily Apataniinae, questions do arise about relationships and classification for the other three genera involved in this paperImania, Manophylax, and Moselyana.

Up to now concepts about relationships of Imania and Moselyana have been based on morphology of adults. Imania was assigned originally to the Apataniinae by Martynov (1935). In his revision of the Limnephilidae, Schmid (1955) placed Imania and Moselyana with the Dicosmoecinae. In a later re-evalution, Schmid (1968) transferred both genera to the Apataniinae and stated that Imania and Moselyana were closely related. The new genus Manophylax, on the basis of adults, is most similar to Imania.

Evidence from the larvae now made available for these genera is analysed below in terms of ancestral and derivative character states. Listed on the left hand side of Table 1 are character states that appear to have been ancestral for the Limnephilidae as a whole. These conditions can be recognized in other families such as the Phryganeidae, Phryganopsychidae, and Limnocentropodidae-families indicated by existing evidence to be closely

Figs. 44-47 Moselyana comosa Denning pupa and larva. 44. Head of pupa, facial view, X53. 45. Pupal abdomen: a, dorsal view, X18, with sclerotized plates enlarged; b, anal processes, dorsal view, X95. 46. Pupal case: a, anterior closure membrane, facial view, X17; b, posterior end, facial view, X20. 47. Maxillae and labium of larva, ventral view, X244. 


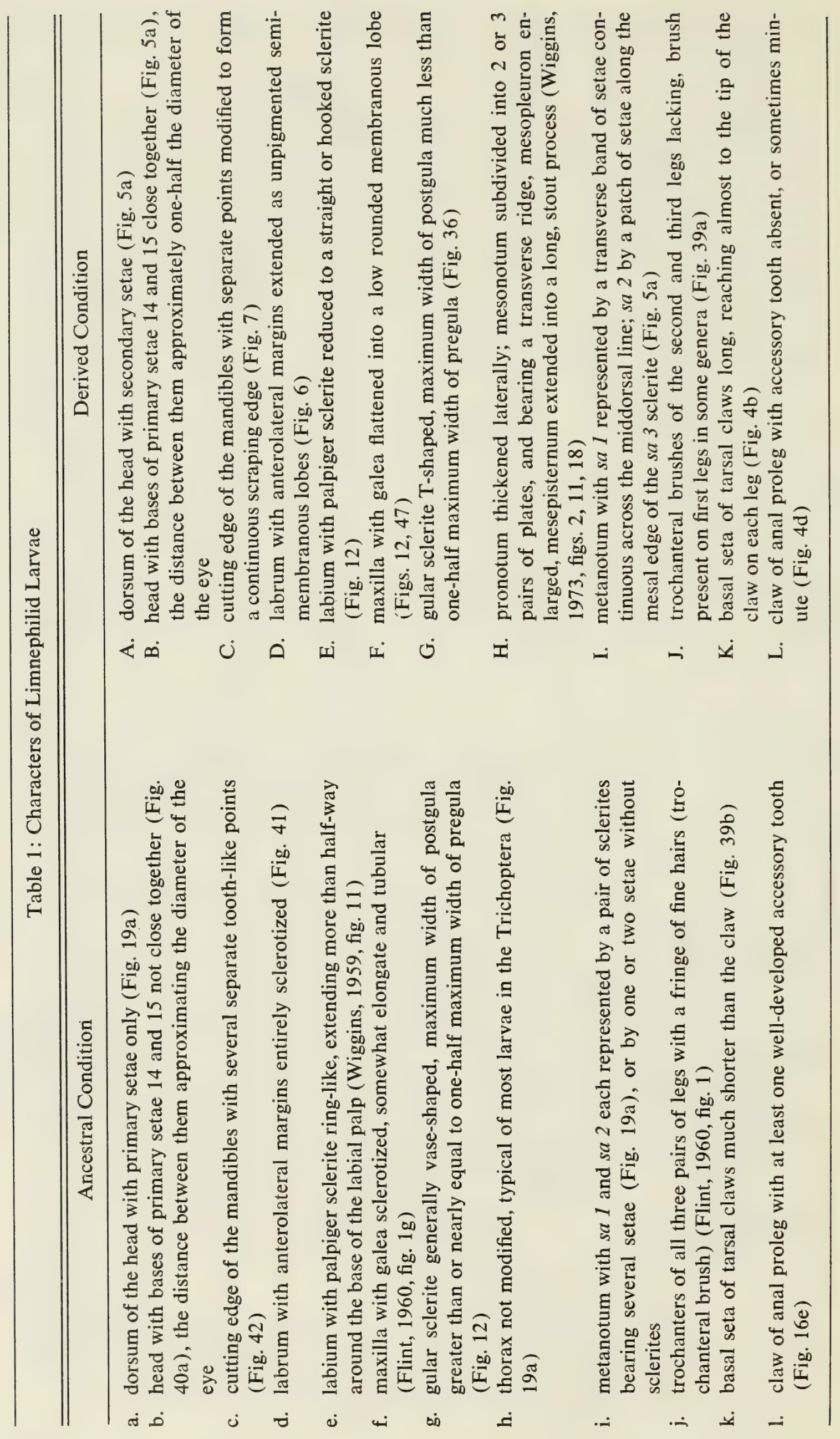


Table 2: Analysis of larval characters from Table 1

(derived character states underlined)

\begin{tabular}{|c|c|c|c|c|c|c|c|}
\hline 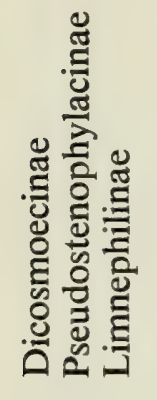 & 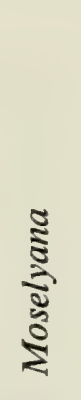 & 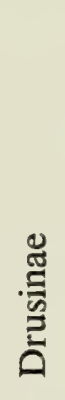 & 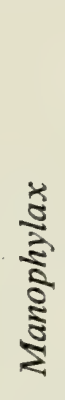 & 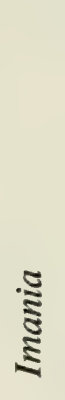 & 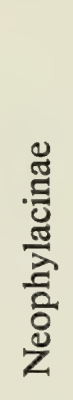 & 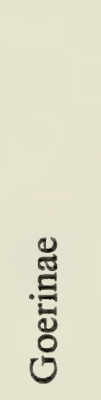 & 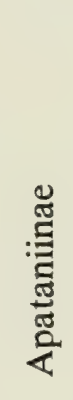 \\
\hline $\mathrm{h}$ & $\mathrm{h}$ & $\mathrm{h}$ & $\mathrm{h}$ & $\mathrm{h}$ & $\mathrm{h}$ & $\mathrm{H}$ & $\mathrm{h}$ \\
\hline $\mathrm{i}$ & $\mathrm{i}$ & $\mathrm{i}$ & $\mathrm{i}$ & $\mathrm{i}$ & $\mathrm{i}$ & $\mathrm{i}$ & I \\
\hline 1 & 1 & 1 & 1 & 1 & 1 & L & L \\
\hline a & A & A & $\mathrm{a}$ & $\mathrm{a}$ & $\mathbf{a}$ & $\mathrm{a}-\mathrm{A}$ & A \\
\hline e & $\mathrm{E}$ & e & $\mathrm{e}$ & $\mathrm{e}$ & $\underline{E}$ & $\mathrm{E}$ & $\mathrm{E}$ \\
\hline $\mathrm{g}$ & $\mathrm{g}$ & $\mathrm{g}$ & $\mathrm{g}$ & $\mathrm{G}$ & G & $\mathrm{g}-\mathrm{G}$ & $\mathrm{g}$ \\
\hline b & $\mathrm{b}$ & b & $\mathrm{B}$ & B & $\mathrm{B}$ & b-B & B \\
\hline $\mathrm{f}$ & $\mathrm{F}$ & f & $\mathrm{F}$ & $\mathrm{F}$ & $\mathrm{F}$ & $\mathrm{F}$ & $\mathrm{F}$ \\
\hline c & $c$ & $\mathrm{C}$ & $\mathrm{C}$ & $\mathrm{C}$ & $\mathrm{C}$ & $c-C$ & C \\
\hline k & $\mathrm{k}$ & $\mathrm{K}$ & $\mathrm{K}$ & $\mathrm{K}$ & $\mathrm{K}$ & $\mathrm{k}-\mathrm{K}$ & $\mathrm{K}$ \\
\hline d & $\mathrm{d}$ & $\mathrm{D}$ & $\mathrm{D}$ & $\mathrm{D}$ & $\mathrm{D}$ & $\mathrm{D}$ & D \\
\hline $\mathrm{j}$ & $\mathrm{J}$ & $\mathbf{J}$ & $\mathbf{J}$ & $\mathbf{J}$ & $\mathbf{J}$ & $\mathbf{J}$ & $\mathbf{J}$ \\
\hline
\end{tabular}

related to the Limnephilidae, yet to represent more primitive evolutionary levels (Flint, 1960; Ross, 1967; Wiggins, 1959, 1962, 1969, 1973). It seems probable that the state of these characters in the generally more primitive, yet related families will represent their ancestral state in the Limnephilidae. In Table 1 ancestral character states are identified by lower case letters, and beside each one is a derived state of the character, represented by the corresponding capital letter. Other larval characters exhibit differences that are useful for grouping, but evidence is not available to permit distinction between primitive and derived conditions.

Larval characters for the seven subfamilies of the Limnephilidae are analysed in Table 2, along with those of the three genera treated in the first part of this paper for which relationships are in question. It should be pointed out that, apart from Imania, Manophylax, and Moselyana, larvae are available to me for only a small part of the genera in these subfamilies. But, as far as I have been able to ascertain, relevant data published by other authors are consistent with the generalizations offered here. 
For the characters analysed (Table 2 ), there is a remarkably consistent retention of ancestral states in larvae of the Dicosmoecinae, Pseudostenophylacinae, and Limnephilinae. On the other hand, the Drusinae, Neophylacinae, Apataniinae, and Goerinae exhibit a series of transformations to derived states. Larvae of the Apataniinae show a derivative state in nine of eleven characters analysed. Phyletic lines leading to Moselyana, Imania, and Manophylax exhibit fewer characters in a derivative state, indicating that larvae of the apataniine genera evolved along different phyletic lines. But, the analysis does reveal that Imania and Manophylax share some derivative character states with the Apataniinae which Moselyana does not. Therefore, evidence from larvae does not support the interpretation based on adults (Schmid, 1968 ) that Imania and Moselyana are closely related and that these genera should be grouped with the Apataniinae. In terms of functional taxonomy, inclusion of Moselyana, Imania, and Manophylax in the Apataniinae adds no new characters to the diagnosis for the subfamily and nullifies those that did exist. Because the diagnosis for larvae of the Apataniinae is based on the derivative characters analysed in Table 2 , it can readily be seen why the diagnosis cannot accommodate these genera.

Several points are, of course, involved. Although practical classification is not a necessary condition to be met by phylogeny, the two seem often enough compatible in the Trichoptera that discord between them cannot be ignored. Furthermore, larval characters within the Trichoptera are largely consistent with family groups that also are concordant with characters of adults, and therefore interpretations of affinities that leave the two sets of data in discord are open to question.

These data are offered to suggest that affinities of Moselyana, Imania, and Manophylax should be interpreted with particular caution, and I admit to being unable at this point to offer a positive position. I am aware of no close relatives for any of these genera, and I believe it would be difficult to assign them to any of the existing subfamilies as now constituted. A better understanding of their relationships must await a general interpretation of phylogeny for the Limnephilidae as a whole, based upon information from all stages, an undertaking for which I do not yet have sufficient data. For the present I prefer to regard Moselyana, Imania, and Manophylax as incertae sedis and not assigned to any subfamily. One of the problems to be resolved is that posed by character states that may be of polyphyletic origin-perhaps represented in characters $\mathrm{a}, \mathrm{e}$, and $\mathrm{f}$ in Table 2 . Within the Goerinae there is evidence of the independent origin for several character transformations (a-A, etc.), based largely on data from the genus Lepania which are treated elsewhere (Wiggins, 1973). 


\section{Acknowledgments}

Specimens and observations for this paper were acquired during field studies supported by the National Science Foundation (Grant G22135), and later the National Research Council of Canada (Grant A5707), and the Fisheries Research Board of Canada. This support is gratefully acknowledged. I am indebted to Dr. N. H. Anderson, Department of Entomology, Oregon State University, and to Mr. S. G. Jewett Jr., West Linn, Oregon, for facilitating my field work in several ways. For assistance with field operations, I am grateful to Messrs T. Yamamoto, I. M. Smith, A. Odum and the late R. S. Scott. Illustrations were drawn by Mr. A. Odum (larvae and pupae) and by Miss A. E. Hillmer (adults). I thank Dr. F. Schmid for a critical review of the manuscript. 


\section{Literature Cited}

DENNING, D. G.

1949 A new genus and five new species of Trichoptera. J. Kans. Ent. Soc., vol. 22 , no. 3 , pp. $88-93$.

FLINT, O. S. JR.

1960 Taxonomy and biology of nearctic limnephilid larvae (Trichoptera), with special reference to species in eastern United States. Entomologica Am., n.s., vol. 40, pp. 1-120.

LEVANIDOVA, I. $M$.

1967 Materiali po faune rucheinikov (Trichoptera) Sibiri i Dal-nevo Vostoka [Data on the caddisfly fauna (Trichoptera) of Siberia and the Far East.] Ent. Obozr., tom. 46, no. 4, pp. 793-798. [In Russian]

MARTYNOV, A. V.

1935 Trichoptera of the Amur Region. Part I. Trudy Zool. Inst., Leningr., vol. 2, (1933-1935), pp. 205-395.

NIELSEN, A.

1942 Uber die Entwicklung und Biologie der Trichopteren, mit besonderer Berücksichtigung der Quelltrichopteren Himmerlands. Arch. Hydrobiol., suppl. band 17, pp. 255-631.

1957 A comparative study of the genital segments and their appendages in male Trichoptera. Biol. Skr., vol. 8, no. 5, pp. 1-159.

ROSS, H. H.

1950 Synoptic notes on some nearctic limnephilid caddisflies (Trichoptera, Limnephilidae). Am. Midl. Nat., vol. 43, no. 2, pp. 410-429.

1959 Trichoptera. In Edmondson, W. T. ed. Freshwater biology. 2d ed. New York, Wiley, pp. 1024-1049.

1967 The evolution and past dispersal of the Trichoptera. A. Rev. Ent., vol. 12, pp. 169-206.

SCHMID, F.

1953 Contribution à l'étude de la sous-famille des Apataniinae (Trichoptera, Limnophilidae). I. Tijdschr. Ent., vol. 96, no. 1-2, pp. 109-167.

1954 Contribution à l'étude de la sous-famille des Apataniinae (Trichoptera, Limnophilidae). II. Tijdschr. Ent., vol. 97, no. 1-2, pp. 1-74.

1955 Contribution à l'étude des Limnophilidae (Trichoptera). Mitt. Schweiz. Ent. Ges., vol. 28, 245 pp.

1968 Quelques Trichoptères néarctiques nouveaux ou peu connus. Naturaliste Can., vol. 95, pp. 673-698.

WIGGINS, G. B.

1959 A new family of Trichoptera from Asia. Can. Ent., vol. 91, no. 12, pp. 745-757.

1962 A new subfamily of phryganeid caddisflies from western North America (Trichoptera: Phryganeidae). Can. J. Zool., vol. 40, no. 5, pp. 879-891.

1969 Contributions to the biology of the Asian caddisfly family Limnocentropodidae (Trichoptera). Life Sci. Contr., R. Ont. Mus., no. 74, pp. 1-29.

1973 New systematic data for the North American caddisfly genera Lepania, Goeracea and Goerita (Trichoptera: Limnephilidae). Life Sci. Contr., R. Ont. Mus., no. 91, pp. 1-33. 


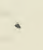




